\title{
LA GALERÍA DE RETRATOS DE LA CASA REAl de Aragón en NÁPoles
}

\author{
David Gimilio SANZ
}

Museo de Bellas Artes de Valencia

Resumen: La existencia inédita de una galería de retratos de la casa real de Aragón en Nápoles procedente del monasterio de San Miguel y de los Reyes de Valencia, localizada en el Museo de Bellas Artes de Valencia permite establecer vínculos con la corte virreinal de los duques de Calabria en Valencia, plantear un estado de la cuestión sobre la posible autoría de la serie pictórica y sugerir algunas consideraciones sobre la imagen de la monarquía de una dinastía extinta.

Palabras clave: retratos reales, casa real de Aragón, Nápoles, duque de Calabria, Valencia.

ABSTRACT: The unprecedented existence of a gallery of portraits of the royal family of Aragon in Naples from the monastery of St. Michael and the Kings of Valencia, located in the Museum of Fine Arts in Valencia, allows to establish a linke with the viceregal court of the Dukes of Calabria in Valencia, raising questions regarding the possible authership of the pictorial series and suggest some considerations on the image of an extinct monarchy dynasty.

Keywords: Royal portraits, Royal Lineage of Aragon, Naples, Duke of Calabria, Valencia. 
$\mathrm{E}^{\mathrm{n}}$ n el Museo de Bellas Artes de Valencia existe una galería de retratos de la casa real de Aragón en Nápoles procedentes del monasterio de San Miguel y de los Reyes de Valencia conformada por nueve retratos de cuerpo entero que representan al duque de Calabria y a su esposa, Germana de Foix, y a los antepasados del duque como reyes de Nápoles [Fig. 1]. Así, la serie se compone de Ferrante I de Aragón e Isabel de Chiaromonte que inician la dinastía, Alfonso II de Aragón e Hipólita María Sforza, Ferrante II de Aragón (más conocido como Ferrandino de Aragón), Federico I e Isabel de Baucio y, por último, Fernando de Aragón y Germana de Foix, mencionados anteriormente. ${ }^{1}$

Estos retratos ingresaron en el Museo de Bellas Artes de Valencia como anónimos fruto de la desamortización eclesiástica y fueron agrupados e identificados con el número 18 del inventario de 1838, aunque existen desajustes entre lo citado y lo ingresado. ${ }^{2}$ La serie se dividió en dos grupos de manera aleatoria para ser depositada en dos instituciones valencianas en los años 50 y 70 del siglo pasado. Los retratos de Fernando de Aragón, de Federico de Aragón, de Isabel de Baucio y el de Germana de Foix fueron a parar a la Audiencia Territorial según la Orden Ministerial de 29 de febrero de 1952, mientras que el resto de retratos (el de Isabel de Chiaromonte, el de Alfonso II de Aragón, el de Hipólita María Sforza, el de Fernando II de Aragón y el del duque de Calabria) fueron depositados en la Delegación del Gobierno en Valencia, según Orden Ministerial de 23 de enero de $1970 .^{3}$

1. Ferrante I, O/L, $177 \times 101 \mathrm{~cm}$. No inv. 2558. Isabel de Chiaromonte, O/L, $170 \times 102 \mathrm{~cm}$. No inv. 3568. Alfonso II, O/L, $230 \times 135 \mathrm{~cm}$. No inv. 3572. Hipólita María Sforza, O/L, $230 \times 137 \mathrm{~cm}$. No inv. 3561. Ferrante II, O/L, $170 \times 102 \mathrm{~cm}$. No inv. 3570. Federico I, O/L, $180 \times 102 \mathrm{~cm}$. No inv. 2665. Isabel de Baucio, $\mathrm{O} / \mathrm{L}, 178 \times 101 \mathrm{~cm}$. № inv. 2664. Fernando de Aragón, O/L, $172 \times 102 \mathrm{~cm}$. No inv. 3569. Germana de Foix, O/L, $176 \times 102 \mathrm{~cm}$. No inv. 2557.

2. $\mathrm{N}^{\circ}$ 18. Nueve retratos de los Duques de Calabria, que son un cuadro que contiene al Duque y la Duquesa, otro de Doña Julia de Aragón, otro de D. Alfonso $5^{\circ}$ de Aragón, otro de D. Fernando de Aragón, otro de D. Juan de id, otro de D. Fadrique de id, otro de $\mathrm{D}^{\mathrm{a}}$ Ursula Germana de Foix, otro de $\mathrm{D}^{\mathrm{a}}$ Isabel de Baucio, otro de $\mathrm{D}^{\mathrm{a}}$ Isabel de Claromonte, otro de D. Alfonso de Aragón. Inventario General o copia de los inventarios particulares de las Pinturas, Esculturas y Gravados que han tenido ingreso en el Depósito de efectos artísticos y cientificos, sito en el estinguido Convento del Carmen Calzado, como procedentes de los Conventos suprimidos en esta provincia de Valencia, así por entregas hechas por la Comisión primitiva, como por la Amortización de la Capital, por los comisionados de la misma en los partidos y por los comisionados de la misma en los partidos y por los encargos de la Yglesias que han quedado sin uso. Valencia, 1838 (manuscrito). En el inventario no se citan los lienzos del duque de Calabria, de Ferrante II, de Hipólita María Sforza y de la infanta Isabel; y se mencionan dos más: el de Alfonso V y el de Juan de Aragón no localizados. Estos dos últimos se podrían relacionar con los retratos reales procedentes del convento de Santo Domingo de Valencia aunque aparecen igualmente citados en su correspondiente asiento, $n^{\circ} 24$ y 23 respectivamente y que son obra de Vicente Salvador Gómez.

3. Este último grupo se ha levantado temporalmente el depósito según Orden Ministerial de 20 de julio de 2010 con motivo de las obras de rehabilitación del edificio histórico sito en el convento del Temple. En cuanto al retrato de Germana de Foix se levantó el depósito anteriormente (O. M. 11 de diciembre de 2006) para ser restaurado con ocasión de una exposición sobre la Corona de Aragón, y por tanto es el único que tiene un estado de conservación óptimo. En el año 2006 este retrato fue depositado en el Museo de Historia de Valencia ilustrando su férreo virreinato, de donde se ha levantado el depósito en diferentes ocasiones para participar en exposiciones temporales sobre el Humanismo y el Renacimiento valenciano. 


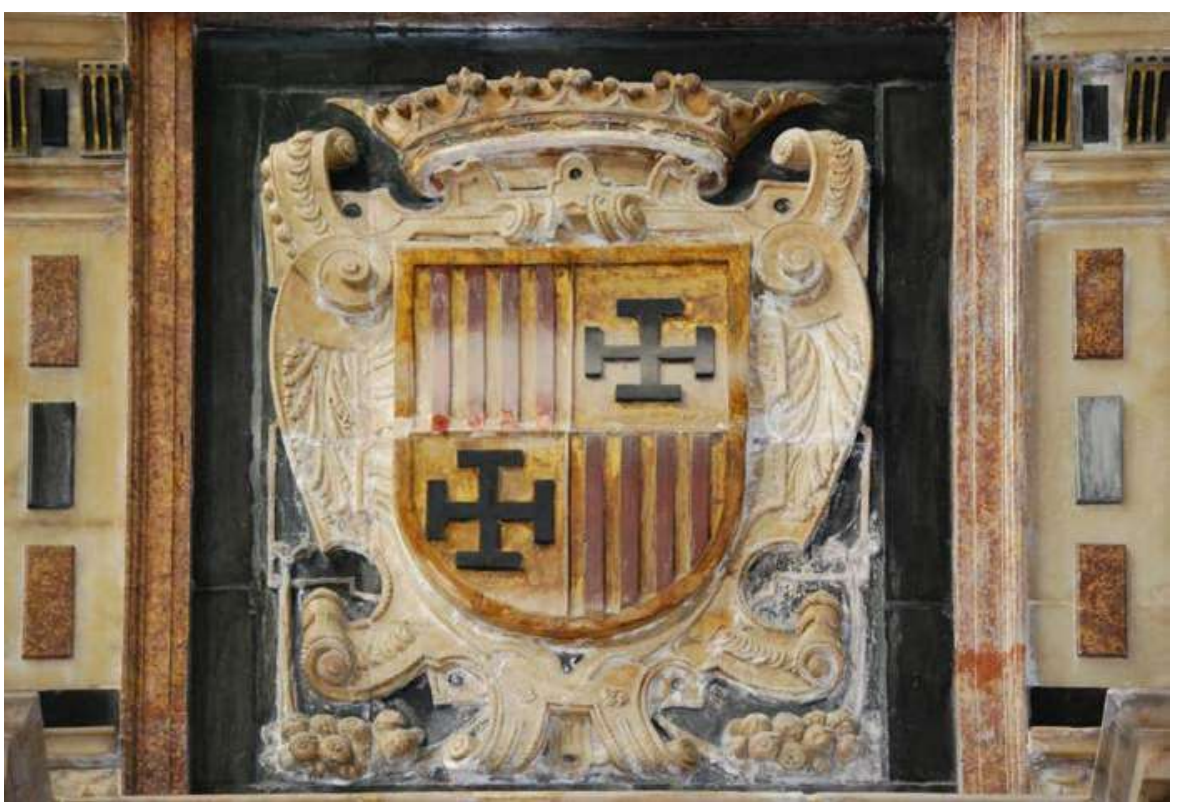

Fig. 1. Escudo del duque de Calabria en su tribuna funeraria de la iglesia del monasterio de San Miguel y de los Reyes. Valencia

Esta serie resulta especialmente interesante por dos motivos, el primero por la relativa ausencia de retratos reales en tierras valencianas, tal y como lo manifiesta Tormo en su libro Las viejas series icónicas de los Reyes de España de $1916^{4}$ donde tan solo menciona una galería de retratos reales del palacio de la Generalitat, extraída a su vez de la publicación de Martínez Aloy y los doce retratos reales que el patriarca Ribera compró a Antonio Rizzi en 1592 que ornaban el aposento de los reyes en el palacio del Huerto de la calle Alboraya y que en 1615 pasaron a decorar la biblioteca del colegio. ${ }^{6} \mathrm{El}$ segundo por el carácter inédito de esta serie de la casa real de Aragón en Nápoles que tan solo es citada por Luis Arciniega al describir la fundación del monasterio de San Miguel y de los Reyes de Valencia. ${ }^{7}$ Sin embargo, esta galería de monarcas de la casa real de Aragón en Nápoles no fue la única en España, puesto que

4. Elías Tormo: Las viejas series icónicas de los Reyes de España, Madrid, Junta de Iconografía Nacional, 1916

5. José Martínez Aloy: La Casa de la Diputación, Valencia, 1909-1910, pp. 58-59, el autor cita la serie de retratos de toda la dinastía aragonesa (Jaime I, Pedro I, Alfonso I, Jaime II, Alfonso II, Pedro II, Juan I, Martín, Fernando I, Alfonso III, Juan II, Fernando II) que proceden del derruido palacio real.

6. Fernando Benito Doménech: Pinturas y pintores en el Real Colegio de Corpus Christi. Valencia, Federico Doménech, 1980. pp. 309-312, números, 212-223. Los retratos son los de Alfonso XI, Enrique IV, Isabel la Católica, el emperador Carlos y la emperatriz Isabel de Portugal, Felipe II, María de Austria, Juana princesa de Portugal, el príncipe Carlos, Isabel Clara Eugenia, Felipe III y Margarita de Austria. Según el autor, esta serie obedece a un sentido genealógico del Patriarca.

7. Luis Arciniega García: El Monasterio de San Miguel de los Reyes, 2 vols., Valencia, Biblioteca Valenciana, 2001, tomo I, p. 26 
el viajero centro europeo, Diego Cuelvis, al recorrer el alcázar de Madrid en 1599 vio en una de las salas, los retratos de «Ferdinandus I, Alonso primo, Alonso II, Fernando II y Federico Rey» que Falomir considera identificables con los reyes de Nápoles de la dinastía aragonesa. ${ }^{8}$ Un dato que pone de relieve la importancia de las series dinásticas en su deseo de apelar a la historia para reclamar la legitimidad de su poder en unos territorios, que en este caso reside en un linaje previo, que confluyó en la configuración primero de la Corona de Aragón y después de los reinos hispánicos. Unas galerías de monarcas que tipológicamente siguen perviviendo de forma vital en los siglos XVI y XVII frente al ascenso del llamado retrato moderno del monarca. Además, y ya en territorio italiano, más concretamente en la iglesia del convento de San Domenico Maggiore de Nápoles se localiza una serie de lienzos de cuatro retratos que representan a algunos de los monarcas aragoneses de esta dinastía (Alfonso I el Magnánimo, Ferrante, Fernando II de Nápoles y Juana IV de Aragón, esposa de este último) que sirven como identificación de los correspondientes y originales depósitos fúnebres o arcas reales que estaban dispuestas a lo largo de las galería de la sacristía de la iglesia napolitana, si bien la cronología del autor se retrasa al primer cuarto del siglo XviII. ${ }^{9}$

\section{LA IDENTIFICACIÓN DE LOS PERSONAJES RETRATADOS}

Sobre la genealogía de la casa real napolitana todavía sigue siendo un referente la obra del marqués de Caldas de Montbuy. ${ }^{10}$ La dinastía se inicia con Ferrante I Nápoles (1423-1494) [Fig. 2]. Hijo natural de Alfonso V de Aragón quien le aseguró un buen futuro cediéndole el trono de Nápoles y Sicilia, para ello lo casó con Isabel de Chiaromonte (también retratada en la serie) sobrina y heredera del príncipe Juan Antonio Orsini de Taranto (sucesor de los derechos de los Brienne al trono de Jerusalén), en definitiva una política matrimonial muy acorde con la época, iniciada por Alfonso $\mathrm{V}$ y continuada por los descendientes, que tuvo que ser hábil para poder mantener la dinastía en el trono.

Ferrante accedió al trono de Nápoles en 1458 enfrentándose al papa Calixto III que declaró extinta la dinastía de Aragón en la figura de Alfonso V y proclamó que dicho reino era propiedad del papado. Con el fallecimiento de Calixto III cambiaron los signos políticos y su sucesor, Pío II, abandonó la reivindicación de este territorio y reconoció a Ferrante como legítimo soberano. Sin embargo, Juan de Anjou, aprovechando el descontento de la nobleza napolitana, decidió reconquistar el trono de sus antepasados, perdido por su

8. Miguel FAlomir FAUS: «Imágenes y textos para una monarquía compleja», El linaje del Emperador, Cáceres, 24 en. 2000 - 7 en. 2001, Madrid, 2000, pp. 61-77 (p. 61).

9. Josefina Mateu Ibars: «Iconografía real de Aragón en San Domenico Maggiore de Nápoles», Boletín de la Real Academia de Buenas Letras de Barcelona, 29 (1961-1962), Barcelona, pp. 229-238.

10. Carlos Sanllehy y Girona, Marqués de Caldas de Montbuy: Los descendientes legitimados de Alfonso el Magnánimo en el trono de Nápoles, Barcelona, 1951. 


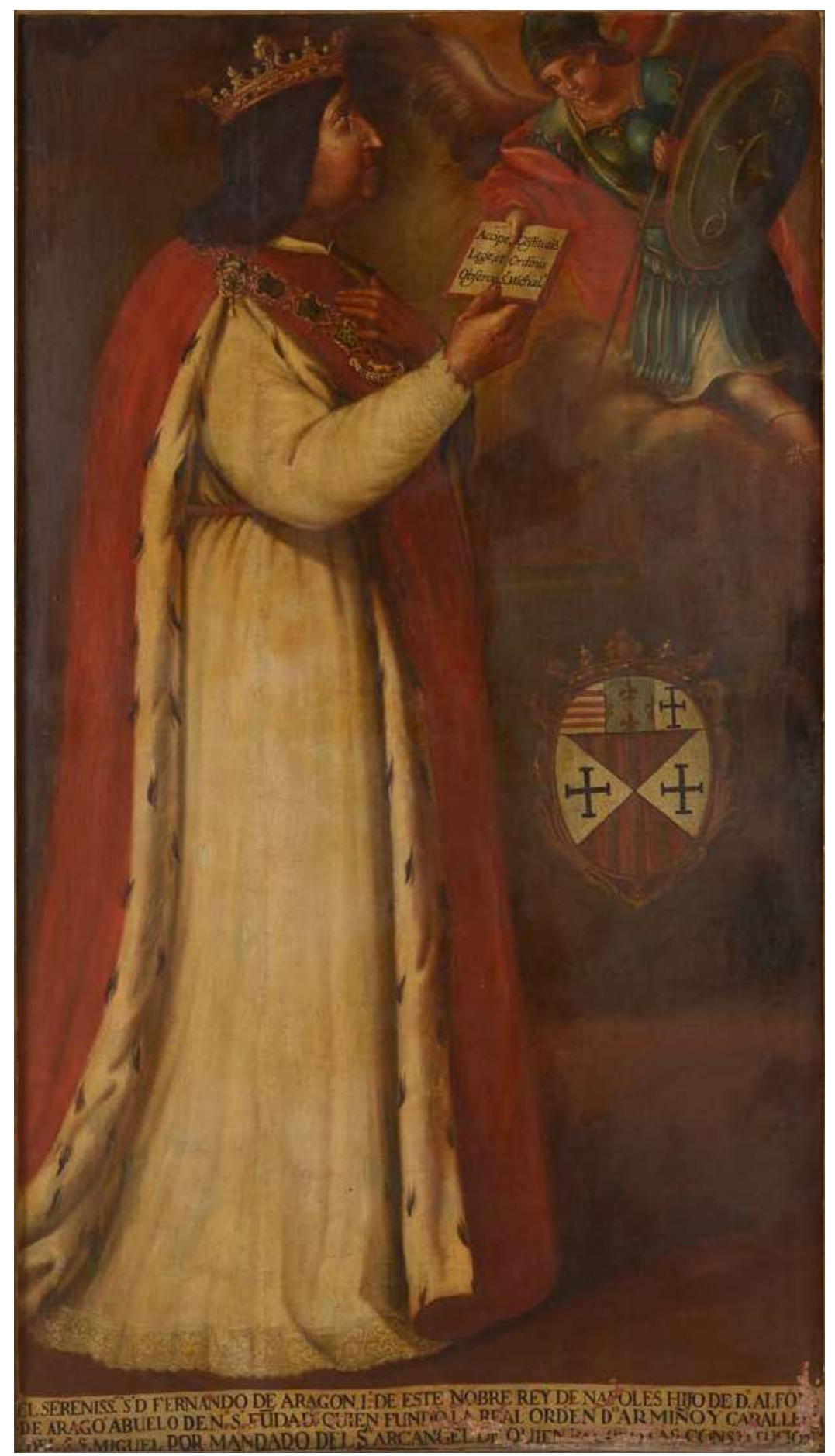

Fig. 2. Gregorio Bausá o Antonio Bisquert, Retrato de Ferrante I de Nápoles, Museo de Bellas Artes de Valencia 


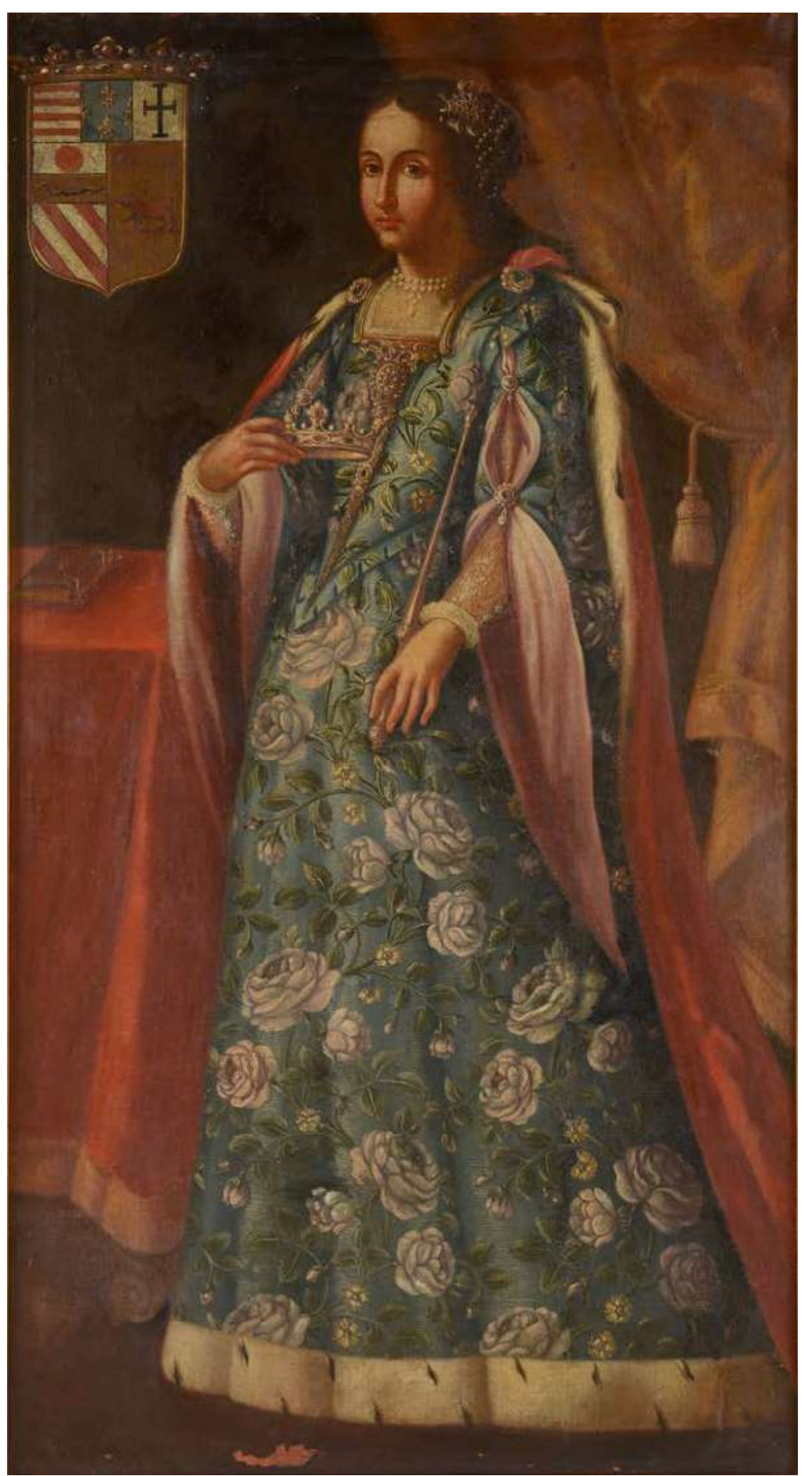

Fig. 3. Gregorio Bausá o Antonio Bisquert, Retrato de Isabel de Chiaromonte, Museo de Bellas Artes de Valencia 
padre, e invadió Nápoles. Este enfrentamiento bélico culminó con la derrota del rey francés, puesto que Ferrante supo aunar los esfuerzos del papado, de Alejandro Sforza y del caudillo albanés Giorgino Castriota Sacanderberg, y así en 1464 restableció su autoridad en el reino.

$\mathrm{Su}$ reinado estuvo marcado por una serie de acontecimientos históricos de cierta envergadura que marcaron su gobierno y el de sus descendientes, configurando una época de gran inestabilidad política, económica y social como fueron la presión otomana de Mehmet II que llegó a ocupar la ciudad de Otranto y puso en jaque al reino cristiano; las revueltas internas como la Conjura de los Barones de 1485 ante su política opresiva y feroz; y por último, la constante amenaza francesa sobre todo con Carlos VIII que terminaron invadiendo el reino y deponiendo al hijo y heredero de Ferrante, Alfonso II.

El matrimonio de Ferrante I con Isabel de Chiaromonte y de Tarento [Fig. 3] le permitió consolidarse en el trono y que dos de sus hijos llegaran a ser reyes de Nápoles (Alfonso II y Federico I), mientras que en sus segundas nupcias con la infanta Juana de Aragón (hija de Juan II el Grande y hermana de Fernando el Católico), tuvo dos hijos, entre los que su primogénita, Juana fue reina consorte de Nápoles al casarse con Fernando II.

Alfonso II de Nápoles (1448-1495) [Fig. 4], apenas fue rey de Nápoles un año, entre 1494 y 1495, que estuvo marcado por el enfrentamiento con Francia y aunque su papel de condottiero le permitió ayudar con su éxito a su padre en diferentes batallas y sublevaciones, como en la mencionada Conjura de los Barones de 1485, en la conspiración de Pazzi y en la guerra de Ferrara, contrasta con el enfrentamiento con el rey Carlos VIII, en el que el monarca francés terminó derrotando a la flota napolitana, obligándole, en cierta manera, a abdicar en su hijo Fernando II y a entrar en un monasterio en Mesina donde moriría en 1495. Además de esta imagen de condottiero, la otra vertiente que marcó su vida, como príncipe del Renacimiento, fue su extraordinaria formación cultural, heredada de su abuelo y de su padre, llegando a ser un importante mecenas de artistas como ejemplifican las villas de La Duchesca y especialmente Poggio Reale en las afueras de Nápoles donde destacaban sus majestuosos jardines con fuentes y amplias avenidas. Además, tuvo como maestro al humanista Giovanni Pontano (1426-1503) ${ }^{11}$ en cuyo $D e$ Principe describió las virtudes y la vida que se debían tener para llegar a ser un príncipe de la modernidad.

Su matrimonio con Hipólita María Sforza (también retratada en la serie) [Fig. 5], hija de Francisco I Sforza estaba dentro de la política matrimonial de alianzas entre el reino de Nápoles y el ducado de Milán necesarias para el mantenimiento de ambas dinastías. Tuvieron tres hijos, Fernando, heredero al trono napolitano, Isabel, casada con su tío el duque de Milán, Gian Galeazzo Sforza, y Pedro, príncipe de Rossano.

11. Claudio Finzi: Giovanni Pontano. Politica e cultura in Napoli aragonese. dialnet.unirioja.es/ descarga/articulo/2864375.pdf. (Consultado: 28 junio 2014) 


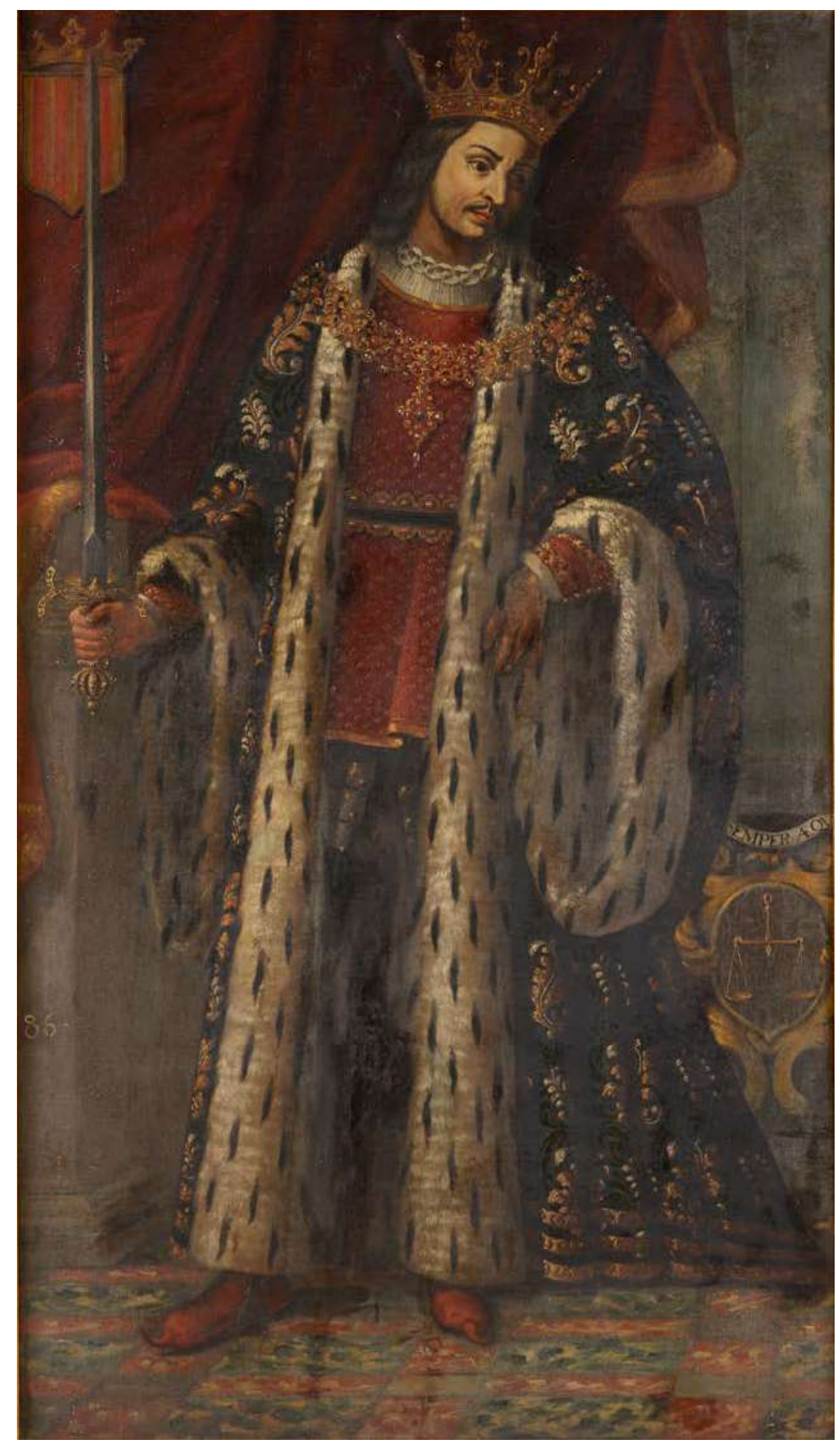

Fig. 4. Gregorio Bausá o Antonio Bisquert, Retrato de Alfonso II, Museo de Bellas Artes de Valencia 


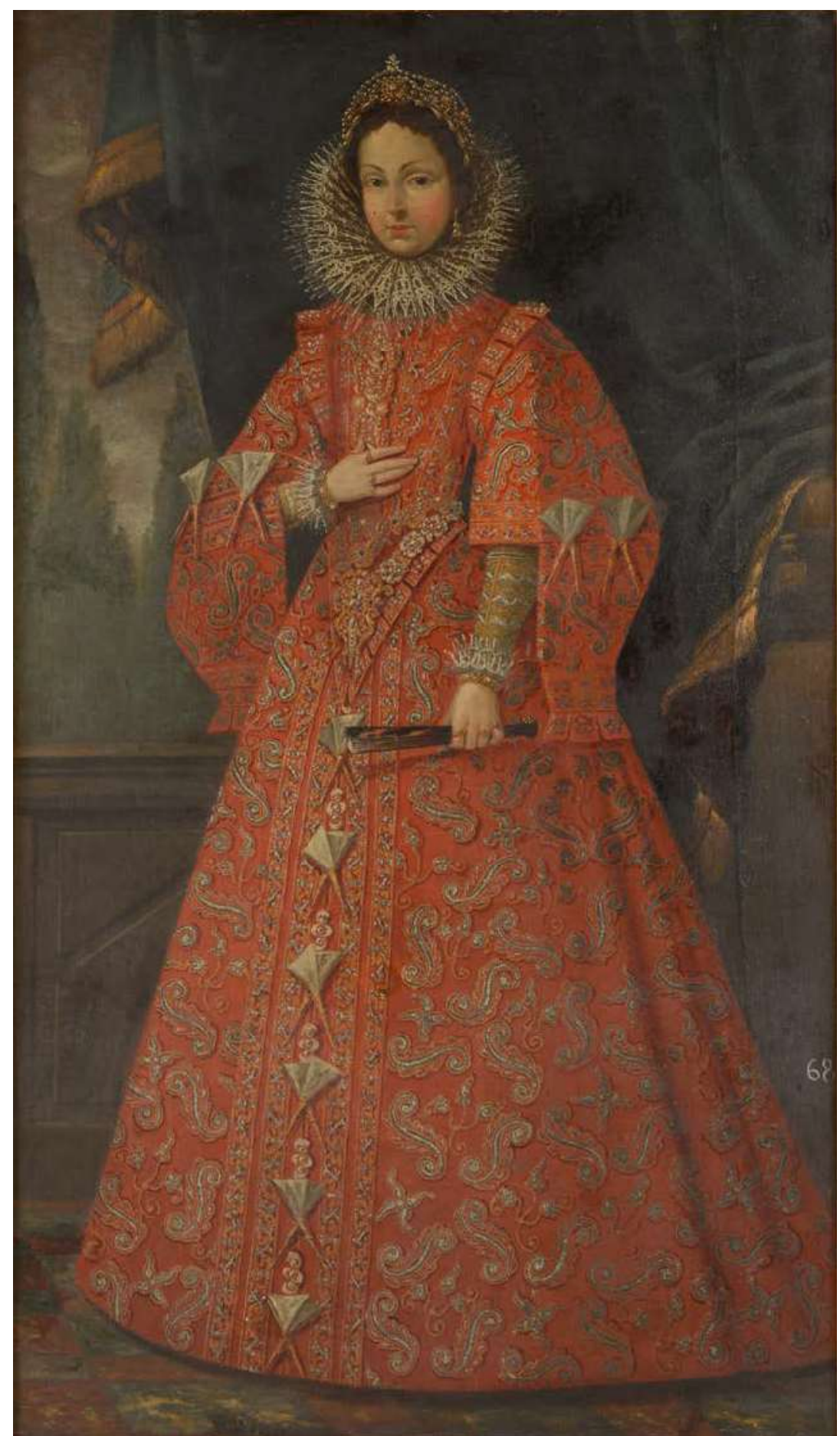

Fig. 5. Gregorio Bausá o Antonio Bisquert, Retrato de Hipólita María Sforza, Museo de Bellas Artes de Valencia 
Fernando II de Nápoles (1469-1496) [Fig. 6]. Su reinado fue tan breve como el de su padre, concretamente entre 1495 y 1496. En el transcurso de la guerra contra Francia, que provocó la abdicación de su padre en él, Fernando II abandonó Nápoles y organizó una liga italiana contra Carlos VIII con la ayuda de las tropas castellanas bajo el mandato de Gonzalo Fernández de Córdoba, el Gran Capitán. Esta actitud heroica junto a la terrible conducta de los conquistadores franceses sobre la población napolitana lo convirtió en un héroe. En 1496 se casó con su tía paterna, Juana de Nápoles, hija de Ferrante I y de su segunda esposa, Juana de Aragón, pero finalmente murió sin descendencia y designó a su tío, el duque Federico de Calabria, como heredero al trono, quien reinaría con el nombre de Federico I. Desgraciadamente, el retrato de la reina Juana no ha llegado a nosotros, quizás por el hecho de no tener descendencia real.

Federico I de Nápoles (1452-1504) [Fig. 7]. Era el segundo hijo de Fernando I y de Isabel de Chiaromonte y fue rey de Nápoles entre 1496 y 1501 tras la muerte de su sobrino, sin embargo, tampoco fue muy feliz su reinado. La alianza entre Luis XII de Francia y Fernando II de Aragón (el rey Católico) para repartirse el reino napolitano llevó a la segunda guerra de Nápoles donde Federico fue depuesto y posteriormente conducido a Tours (Francia) como prisionero donde murió. El reino de Nápoles se mantuvo dividido hasta 1504 cuando según el Tratado de Lyon fue cedido por completo a Fernando II de Aragón que lo unió al reino de Sicilia.

Se casó con Ana de Saboya en primeras nupcias con la que tuvo una hija, Carlota. En su segundo matrimonio se casó con Isabel de Baucio [Fig. 8] con la que tuvo cinco hijos, entre ellos, Fernando de Aragón, duque de Calabria, virrey de Valencia y fundador de San Miguel y de los Reyes.

Por último, los duques de Calabria. Fernando de Aragón (1488-1550) [Fig. 9], hijo de Federico I de Nápoles y de Isabel de Baucio, se encontró separado de su familia y con una dinastía sin trono. Su padre estuvo exiliado en Tours hasta su muerte en 1504 y el resto de su familia vivió en Ferrara bajo la protección de Alfonso d'Este. Mientras tanto, Fernando de Aragón, fue hecho prisionero y trasladado a Alicante en 1502, desde donde fue presentado en la corte española. Cuando el rey Fernando el Católico marchó a Nápoles en 1506 para coronarse rey de aquellos territorios, dejó a Fernando de Aragón como lugarteniente general en el Principado de Cataluña, Reino de Mallorca y condados de Rosellón y Cerdeña. Pese a este cargo de confianza, sufrió cautiverio en los castillos de Atienza y de Xàtiva por una conspiración contra el rey en la que se vio envuelto y del que fue liberado en 1523, iniciando una nueva etapa de plena colaboración con Carlos I como lo demuestra el hecho de que fuera designado embajador extraordinario en la corte portuguesa para recibir a la esposa del emperador. Después de esta tarea, fue nombrado virrey, junto a su esposa Germana de Foix, del Reino de Valencia donde ejercieron el gobierno durante diez años. Tras el fallecimiento de la virreina, Fernando de Aragón volvió a contraer matrimonio en 1541 con Mencía de Mendoza y Fonseca, segunda marquesa de Cenete. 


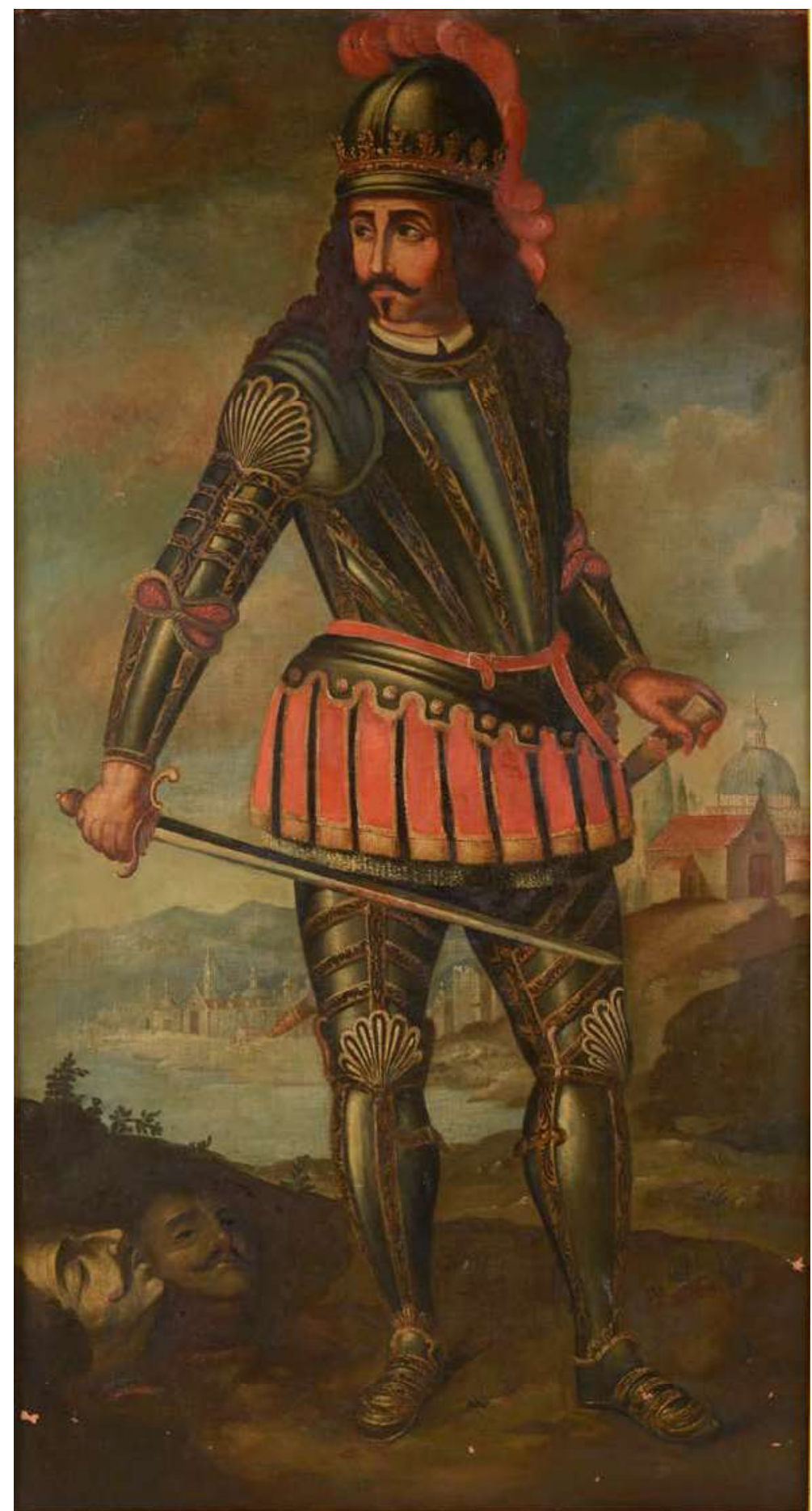

Fig. 6. Gregorio Bausá o Antonio Bisquert, Retrato de Fernando II, Museo de Bellas Artes de Valencia 


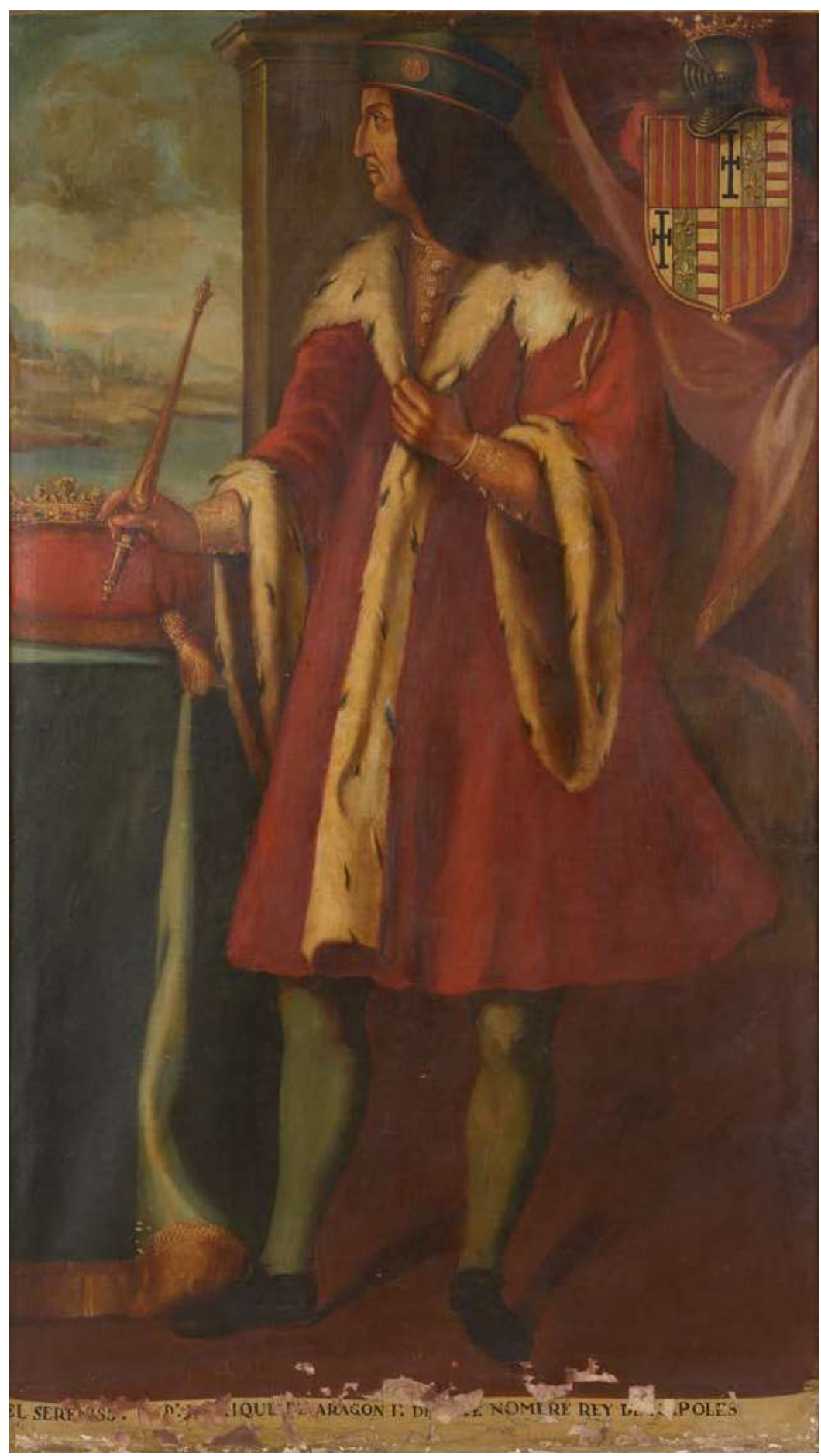

Fig. 7. Gregorio Bausá o Antonio BisquerT, Retrato de Federico I, Museo de Bellas Artes de Valencia 


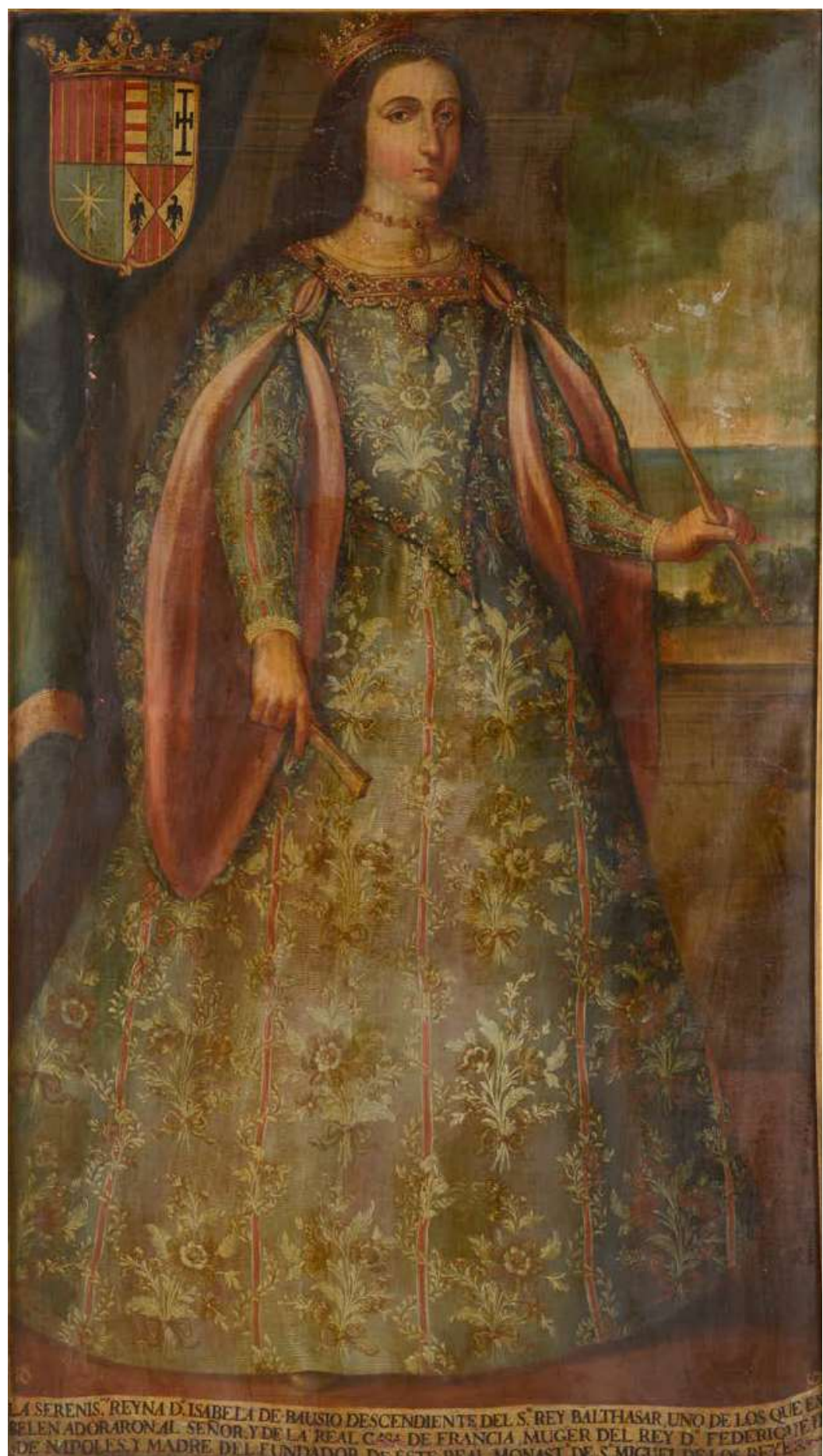

Fig. 8. Gregorio Bausá o Antonio Bisquert, Retrato de Isabel de Baucio, Museo de Bellas Artes de Valencia 


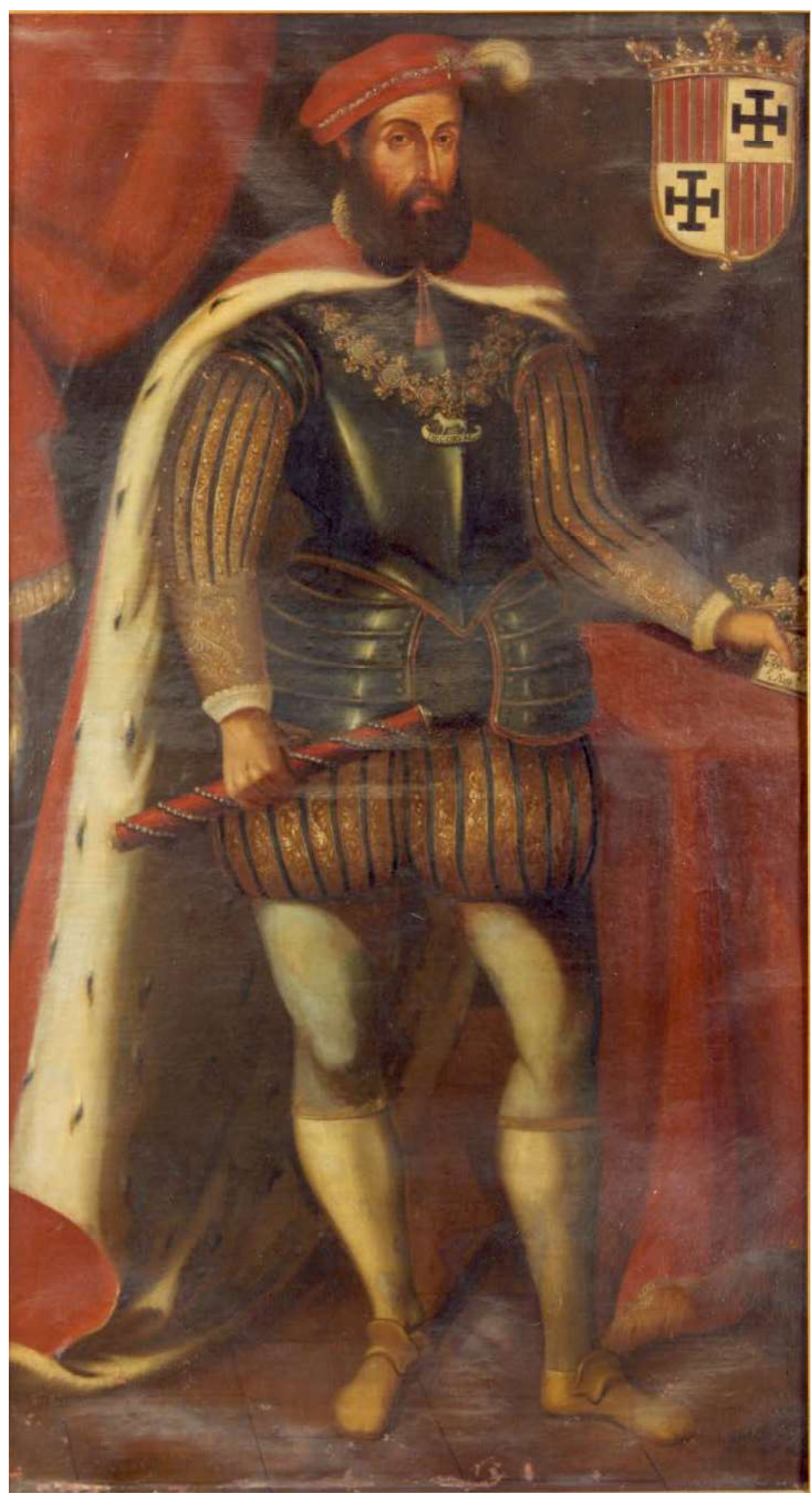

Fig. 9. Gregorio Bausá o Antonio Bisquert, Retrato de Fernando de Aragón, duque de Calabria y virrey de Valencia, Museo de Bellas Artes de Valencia 
En cuanto a Germana de Foix (1488-1538) [Fig. 10], fue hija de Juan de Foix, conde de Étampes y vizconde de Narbona, y de María de Orleans, hermana de Luis XII de Francia. Ella y su hermano, Gastón de Foix, duque de Nemours, quedaron huérfanos a edad temprana y fueron encomendados al rey de Francia. Esta insigne ascendencia le permitió conseguir un relevante matrimonio de estado con Fernando II el Católico en 1506 que duró hasta 1516 y y que le vinculó con los territorios hispánicos de por vida. En 1519 se casó con el marqués de Brandemburgo por orden de Carlos I y se le concedió el título de virreina y lugarteniente del Reino de Valencia en 1523, una vez finalizada la guerra de las Germanías. En 1525 falleció el marqués y se casó nuevamente con don Fernando de Aragón, duque de Calabria, manteniendo el cargo desde donde tomaron las medidas oportunas para fortalecer el poder central.

Junto a las medidas centralizadoras que tomaron Fernando de Aragón y Germana de Foix, en sintonía con la política imperial de Carlos I, se ha de destacar el interés por crear una corte acorde con el estatus de los virreyes donde emulaban las cortes reales donde ellos habían vivido a lo largo de su vida en Francia, Nápoles y en la corte itinerante del emperador. En este marco se entiende el empeño por rehabilitar el Palacio Real de Valencia y decorarlo para su residencia, ${ }^{12}$ así como el desarrollo de las actividades lúdicas e intelectuales sobre todo las literarias y musicales, convirtiéndola en una de las cortes más cultas y activas de la Península. ${ }^{13}$ Una corte con más de doscientas personas de servicio, con gran presencia de personal italiano, que permitió que se fundiera la tradición castellana y la de Borgoña para concebir una etiqueta acorde con la nueva corte y con la majestad de su propio linaje. ${ }^{14}$ Un aspecto que se ha querido apuntar con el fin de captar el ambiente culto y cortesano de este periodo que creemos permite entender la creación del Real Monasterio de San Miguel y de los Reyes.

Al margen de esta galería de retratos de la casa de Aragón en Nápoles, pero estrechamente vinculado al sentir del duque, se han de mencionar dos retratos de las hermanas de Fernando de Aragón, Isabel y Julia [Fig. 11]. Son dos retratos anónimos muy sumarios, de tres cuartos, en un óvalo decorado a modo de rocalla y con sendas inscripciones donde se mencionan a sus padres y a su hermano y que sus cuerpos se encuentran en el panteón del monasterio. ${ }^{15}$

12. Luis Arciniega García: «Construcciones, usos y visiones del palacio del Real de Valencia bajo los Austrias», Ars Longa, 14-15 (2005-2006), pp. 129-164.

13. José Martí Ferrando: «La Corte virreinal valenciana del Duque de Calabria», Reales Sitios, 158, 2003, pp. 16-31.

14. El lujo de las fiestas, los juegos galantes, los bailes, las obras de teatro, las cacerías, etc. no solo se podían disfrutar en el palacio real sino también en la finca de recreo que los duques tenían en Llíria y que sirvió para la recreación de la obra del humanista Luis Milán El Cortesano. Josep Vicent EsCARTí: «Sobre la vida y las ideas de un cortesano renacentista: Luis Milán (1507?-1559)» http://www.ehumanista.ucsb.edu/ volumes/volume_18/pdf/articles/15\%20ehumanista18.escarti.pdf. (Consultado: 2 julio 2014)

15. Retrato de Isabel de Aragón. O/L, $101 \times 76 \mathrm{~cm}$. No inv. 2666. Retrato de Julia de Aragón. O/L, $102 \times$ $71 \mathrm{~cm} . \mathrm{N}^{\circ}$ inv. 2667. 


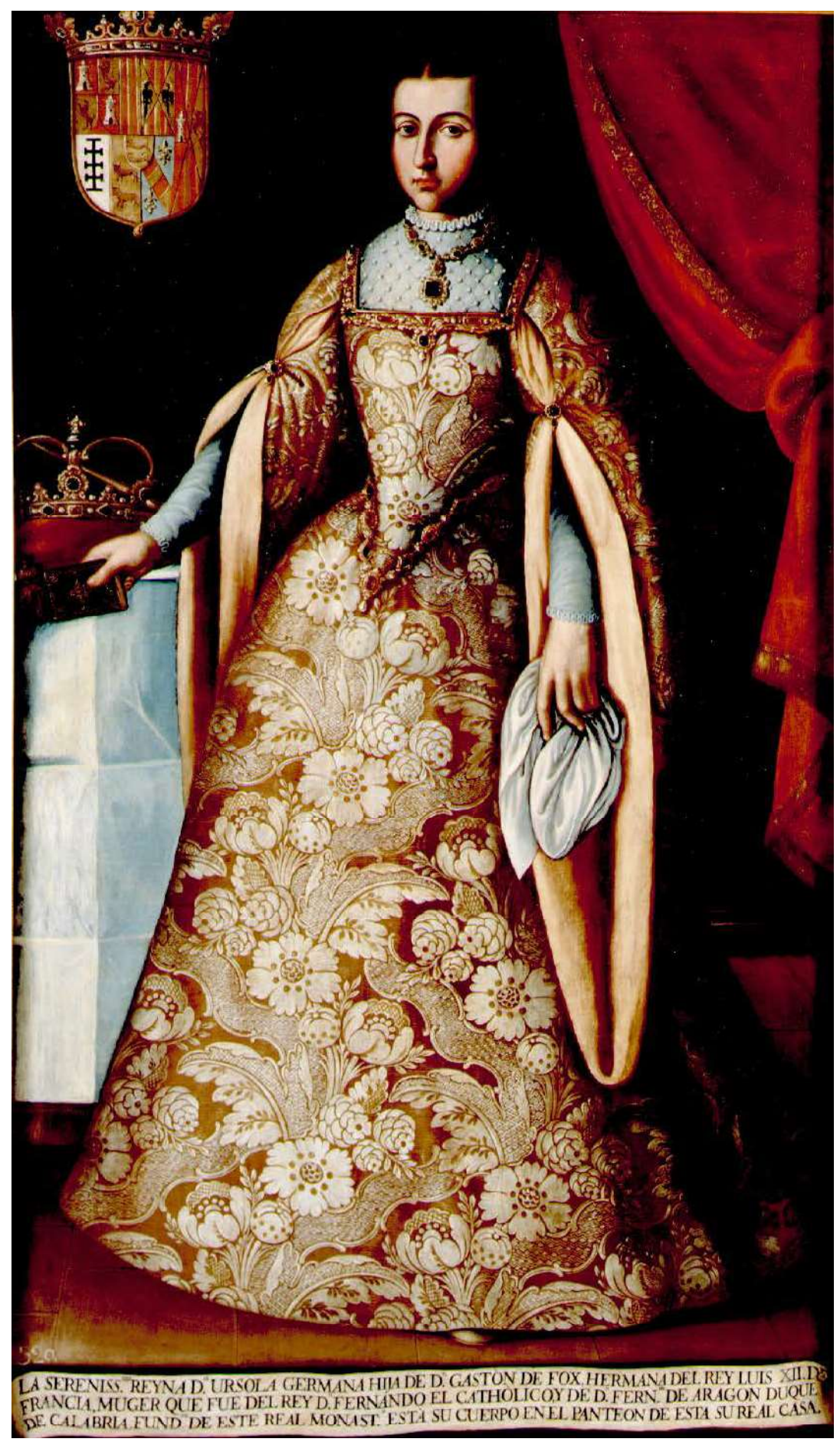

Fig. 10. Gregorio Bausá o Antonio Bisquert, Retrato de Germana de Foix, duquesa de Calabria y virreina de Valencia, Museo de Bellas Artes de Valencia 


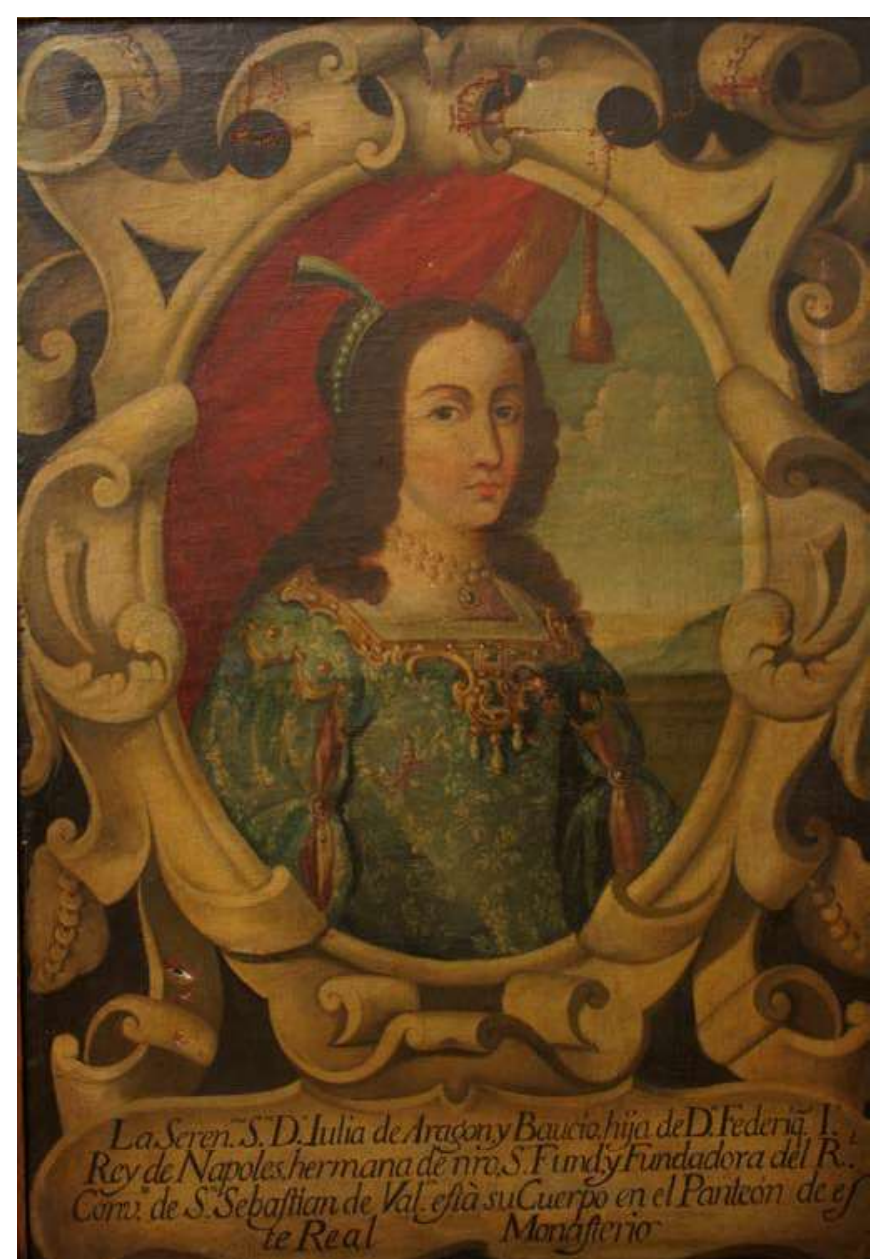

Fig.11. Anónimo, Retrato de Julia de Aragón y Baucio, Museo de Bellas Artes de Valencia

En el caso de la inscripción de la infanta Julia de Aragón, además se especifica que fue la fundadora del Real Convento de San Sebastián de Valencia en $1535 .^{16}$ La presencia de las infantas resultó básica para el duque tras la muerte de su madre en 1533, puesto que era una manera de reunir a su familia desperdigada por los trágicos acontecimientos históricos, con lo que las incorporó a la vida de palacio en 1535 habilitando unas dependencias en el Palacio Real

16. Sobre una antigua ermita dedicada a san Sebastián, los padres mínimos fundan un convento manteniendo la advocación, que bajo el patronazgo de la infanta doña Julia se verá impulsado e incrementado sobre todo al incorporar las reliquias de san Francisco de Paula que fueron dadas en vida del santo al padre del duque de Calabria, según afirma Corachán en la vida dedicada al santo. JUAN BAUTista CorACHÁN: Compendio de la Portentosa vida de San Francisco de Paula, Valencia, Imprenta de Antonio Bordazar, 1733, cap. 4, par. 2, p. 214, nota 48. 
de Valencia llamado Cuarto de las Infantas que constaba de unas galerías con vistas a los espléndidos jardines del Real. ${ }^{17}$

\section{La fundación del monasterio de San Miguel y de los Reyes de} VALENCIA

Sobre la fundación de San Miguel y de los Reyes es de obligada referencia la vasta y completa obra de Luis Arciniega donde se analiza el conjunto desde sus inicios hasta la actualidad en sus diferentes aspectos históricos y artísticos. ${ }^{18}$ Sobre este edificio se citarán algunas características sobre su fundación, que si bien es debido a la última voluntad de la virreina Germana de Foix para ser enterrada, no es menos cierto que el virrey, Fernando de Aragón, duque de Calabria y heredero al trono napolitano hará suyo este proyecto con una mayor ambición y monumentalidad, donde existen una serie de elementos ideológicos marcados por el duque que confieren a este edificio un carácter especial tanto por su construcción como por su destino, y que nos permite establecer un vínculo entre la fundación del monasterio y la creación de la serie.

Este cenobio, de origen cisterciense, se reconstruye y se solicita permiso para acoger una nueva orden, la jerónima, más acorde con los nuevos y reales propietarios. Desde el siglo XV, los reyes de España favorecieron a esta orden por su austeridad y espíritu de penitencia, pero también por el carácter exclusivamente peninsular de la orden que le otorgaba cierta independencia respecto a superiores foráneos. A su vez, los jerónimos se entregaron a los monarcas para que utilizasen y se sirvieran de la orden como propia en una estrecha relación institucional, tal y como lo redacta Fr. José de Sigüenza en su libro sobre la historia de la orden jerónima «no hay cosa en la Orden de San Jerónimo que no sea de la Casa Real». ${ }^{19}$ Quizás, el duque sabedor de esta normativa no escrita, solicitó fundar un monasterio de la orden jerónima en el capítulo general de los jerónimos en el monasterio de San Bartolomé de Lupiana (Guadalajara).

Este concepto de unir la orden jerónima a un gran monasterio con un perfil erudito y culto donde se leyeran artes y teología y donde se contara con la gran biblioteca familiar de los reyes de Nápoles, y que a su vez estuviera enriquecido con las rentas de los duques, se ha de considerar como un trámite necesario para la creación de su gran legado que le recordara a él y a su familia, que se ejemplifica en el gran panteón dinástico y que, en conjunto, se ha de considerar como un precursor del Real Monasterio de El Escorial. Como

17. Arciniega García, Construcciones, usos y visiones, p. 133.

18. Arciniega García, El Monasterio de San Miguel de los Reyes, tomo i, p. 25.

19. F. Javier Campos y Fernández De Sevilla: Los Reyes de España y la orden de San Jerónimo en los siglos $X V$-XVI. p. 6, nota 25.

http://www.javiercampos.com/files/Los\%20Reyes\%20de\%20Espana\%20y\%20La\%20Orden\%20de\%20

San\%20Jeronimo.PDF. (Consultado: 15 mayo 2014) 
propone Arciniega, cuando Felipe II construyó El Escorial existía un claro sentimiento dinástico abierto al mañana donde se une el esplendor del pasado, el presente del monarca y una invitación al futuro; en el caso de San Miguel y de los Reyes es el canto del cisne de una genealogía que ocupó el trono de Nápoles extinta en Fernando de Aragón, el último duque de Calabria. ${ }^{20}$

En 1546, el duque toma posesión del monasterio y manda trasladar los cuerpos de su esposa y de su hermana doña Julia para que recibieran sepultura en la iglesia. Esta idea básica de los enterramientos vinculados a un edificio histórico obviamente no resulta novedoso, sin embargo, a partir del enterramiento de Germana de Foix, Fernando de Aragón, sí que lo magnificará con el encargo a Alonso de Covarrubias de la construcción de una capilla «de los Reyes» de planta cuadrada, pegada al claustro y con remate octogonal que recuerda la sala capitular de la catedral de Valencia o la Sala dei Baroni en Castelnuovo de Nápoles, que se convertiría, al menos en un plano ideológico, en un gran panteón de la casa real de Nápoles. Un proyecto que se fue complicando y modificando, tras el temprano fallecimiento del duque, hasta que se convirtió en una capilla dedicada al Santo Cristo, bastante alejado de esa idea primigenia del duque. Aun así, se construyó un gran edificio con una poderosa arquitectura en su claustro, en la gran escalera principal y obviamente en la gran iglesia donde se despliega una ideología y un programa dinástico de gran presencia, en parte marcado por Fernando de Aragón y seguido por la comunidad jerónima que continuaron incluyendo las armas de la dinastía como signo de agradecimiento, pero también como forma de enaltecimiento para la propia casa. Quizás sea en este punto donde se deba de incluir el encargo de esta serie de retratos de la dinastía de la casa de Aragón en Nápoles.

Aunque este proyecto constructivo se vio interrumpido por problemas económicos, siempre mantuvo el espíritu inicial de los planos de Covarrubias, del programa dinástico ideado por el duque de Calabria y por el seguimiento que la comunidad jerónima hizo de la obra y de las últimas voluntades del fundador. Si Covarrubias firmó las trazas, fue Juan de Vidaña quien la llevó a cabo, pero otros arquitectos y maestros intervinieron en la construcción como Juan Cambra que levantó la escalera imperial o Pedro de Ambuesa que inició la construcción de la iglesia y la fachada en 1623.

Este programa de ensalzamiento dinástico, más que iconográfico propiamente dicho, resulta evidente en la gran fachada-retablo flanqueada por dos grandes torres cuadradas gemelas; una portada donde se sitúan las nuevas advocaciones del monasterio (San Miguel y los Reyes Magos) y donde se puede vislumbrar cierta intención programática [Fig. 12].

En cuanto a san Miguel, existe una doble motivación, por una parte la devoción a este arcángel por parte de los virreyes, evidente en el caso de Germana de Foix que tenía su imagen en su capilla y por la veneración que le profesaba según consta en su testamento. En el caso del duque de Calabria la

20. Arciniega García, El Monasterio de San Miguel de los Reyes, tomo i, p. 25. 


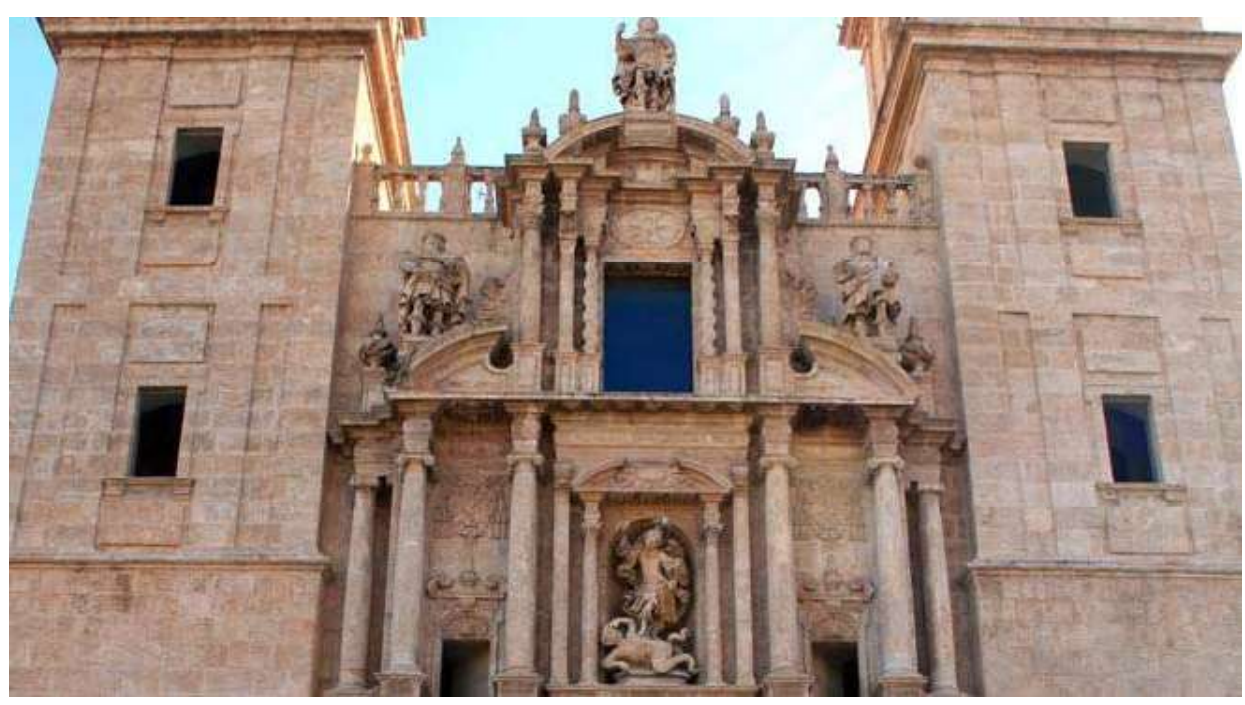

Fig. 12. Detalle de la fachada del monasterio de San Miguel y de los Reyes, Valencia

vinculación es más compleja, puesto que no tiene una significación puramente religiosa sino que va más allá, al retrotraerse a los tiempos de Fernando de Aragón y la institución de la Orden de caballería del Armiño o del Arcángel San Miguel. Esta orden fue instituida por el rey de Nápoles, Fernando de Aragón, en Castelnuovo el 9 de febrero de 1483, la regían 33 capítulos y constituciones que debían guardar 27 caballeros, reyes o ilustres, con el rey de Nápoles a la cabeza. ${ }^{21}$ La insignia de esta orden consistía en un collar de oro del que pende la figura de un armiño acompañado de la frase latina «MALO MORI QUAM FODARI», que significa que es preferible morir que faltar a la fidelidad del soberano. De hecho en el retrato de Fernando de Aragón que porta el collar de oro con el armiño blanco, se ve claramente como el arcángel san Miguel le entrega las constituciones de la orden que lleva su nombre, uniendo los dos elementos simbólicos. En definitiva, una orden, la de San Miguel, vinculada a la familia real de Nápoles que por tanto debe ser protagonista de esta nueva fundación. Esta iconografía del monarca de perfil, levemente modificada (sin el arcángel o enseñando el pinjante del armiño con la inscripción) será utilizada como modelo para el retrato del monarca en la galería de hombres ilustres que don Diego de Vich tuvo en su palacio valenciano y trasladó al monasterio de Nuestra Señora de la Murta en Alzira (Valencia) para finalmente ser recibida por la Real Academia de San Carlos. ${ }^{22}$

21. Arciniega García, El Monasterio de San Miguel de los Reyes, tomo i, p. 54, también en nota 60.

22. Óleo sobre lienzo, $63 \times 49 \mathrm{~cm}$. No inv. 1836. Museo de Bellas Artes de Valencia. Colección de la Real Academia de San Carlos. 
En cuanto a los Reyes Magos, los cronistas señalaban que el monasterio se llamó de los Reyes por los ilustres y reales personajes que estaban enterrados en el panteón, puesto que el duque fue jurado al trono en Nápoles (tal y como aparece en la inscripción de su retrato), Germana fue reina consorte, pero además el monasterio debía albergar los cuerpos de los padres del duque, Federico I y doña Isabel que fueron reyes de Nápoles, así como los hermanos del duque que fueron infantes. Sin embargo, existe una razón de carácter dinástico que aporta Isabel de Baucio, madre del duque de Calabria, puesto que según la tradición la casa de Baucio descendía del rey Baltasar, uno de los tres reyes que acudieron a Belén a adorar a Jesús y por esta razón se representa a los tres Reyes Magos, con lo que el vínculo entre la tradición y el proyecto está firmemente asentado. En definitiva, un programa meditado (del duque o de la comunidad) donde se recogen diferentes elementos del linaje de la casa de Aragón en Nápoles.

\section{LA AUTORÍA DE LA GALERÍA DE RETRATOS. ESTADO DE LA CUESTIÓN}

Estos retratos responden al típico retrato real de cuerpo entero con blasón en los ángulos mientras varía la escenografía, algunos se retratan en una estancia palaciega con un gran vano por donde se abre un paisaje que ilumina el conjunto (como los de Federico I e Isabel de Baucio); en otros se ha prescindido del ventanal y es una cámara cerrada del palacio ricamente decorada con cortinajes y mobiliario (el de los duques de Calabria) y una última variación en la que aparece Ferrante II con armadura en medio de un paisaje. Este tipo de composición y de decoración que reproducen ambientes palaciegos contribuyen a crear una imagen de austeridad, pero también de manifiestas intrínseca a las series regias susceptibles de incluirse en un discurso iconográfico más amplio, como así ocurre con el monasterio de San Miguel y de los Reyes, donde se imbrican los conceptos de retrato y memoria histórica.

Aunque esta serie de retratos recuerda a los de la corte imitando la manera de Moro, Sánchez Coello o Pantoja de la Cruz, lo cierto es que estilísticamente parecen ser más tardíos y por tanto pudiera ser un encargo de los monjes como homenaje a la familia del duque una vez fallecido, una hipótesis no descabellada, ya que una decisión similar tomaron los colegiales del Real Colegio de Corpus Christi de Valencia al encargar a Francisco Ribalta el retrato de Per Afán de Ribera, padre del patriarca Ribera, años después de la muerte de este. ${ }^{23}$

Pero ¿quién en Valencia sería capaz de retratar? Sabemos de la dificultad que existía en España para encontrar retratistas (y también fresquistas) o

23. Benito Doménech: Pinturas y pintores en el Real Colegio de Corpus Christi, nº cat. 186, p. 304. Retrato de Per Afán de Ribera. «Al parecer, quisieron los Colegiales Perpetuos honrar la memoria del fundador encargando a Ribalta dos quadros del Patriarca mi Señor y del duque su padre para adorno de la librería». 
que más bien brillaron por su ausencia. ${ }^{24} \mathrm{El}$ entorno culto y humanista de los duques de Calabria permitiría pensar en Joan de Joanes como el pintor por excelencia para este encargo, una relación cuestionada por Falomir, a partir del escaso interés del duque de Calabria por la pintura y por la escultura en aras de otras artes como la literatura y la música, ${ }^{25}$ si bien, según Benito Doménech y Gómez Frechina, este mecenazgo estaría ampliamente documentado como más tarde se explicará. ${ }^{26}$ Otros artistas alejados del ámbito del duque de Calabria y susceptibles de ser autores de la serie son Apolinario Larraga, Gregorio Bausá o Antonio Bisquert que no solo retrasan la cronología de la serie, sino que también dificultan la certificación de la autoría. Además, esta galería no puede contemplarse como una serie de retratos en sentido estricto, sino que sin duda tienen un referente en estampas, que reproduciendo modos y formas sirvió al artista para crear con cierto aire de solemnidad y prestancia esta galería real.

Como proponen Benito Doménech y Gómez Frechina, la estrecha relación entre Joanes y la corte virreinal del duque de Calabria se evidencia con diferentes y profundas referencias: en la pintura del Juicio de Paris del Museo de Udine donde la rareza del asunto mitológico y la incorporación del desnudo permite asociarla al ambiente humanista de los virreyes, así como en las letras FAR entrelazadas y marcadas a fuego en el reverso de la tabla de Joanes Calavera (Memento mori) del museo valenciano y que parecen responder a las siglas de Fernando de Aragón. Otras obras más fehacientes son el encargo del duque al pintor del retablo mayor de la parroquia de San Esteban de Valencia y un tríptico de la Encarnación de las dominicas de Xàtiva que fue donado por el duque al ingresar su hija natural, sor Jerónima de Aragón. Con mayor seguridad se atribuye un escudo del duque en la portada del Homiliario del doctor Alcunyo (Valencia, 1552), y los retratos de los duques sobre papel que Orellana vio en la celda prioral del monasterio de San Miguel y de los Reyes. Por último, es Gómez Frechina el que da a conocer una inscripción «Fernando de Aragón duque de Calabria» y lo que parece la fecha 1550 en una tabla con la iconografía del Nazareno de la iglesia de Manzanera, una de las villas del virrey, considerada como obra segura de Joanes.

El duque era consciente de la calidad pictórica de Joanes y lo hubiera elegido, sin duda, para encargarle la galería icónica de su linaje, hecho que no sucedió, puesto que la serie que nos ocupa muy poco tiene que ver con el virtuosismo de la factura joanesca que se puede apreciar en otros retratos como el de don Luis de Castellá de Vilanova, señor de Bicorp, del Prado o el

24. Miguel Falomir Faus: «Los orígenes del retrato en España. De la falta de especialistas al gran taller», El retrato español: del Greco a Picasso. Madrid, Museo Nacional del Prado, 20 en. 2004 - 6 feb. 2005. Madrid, 2004, pp. 68-83.

25. Miguel Falomir Faus: «El duque de Calabria, Mencía de Mendoza y los inicios del coleccionismo pictórico en la Valencia del Renacimiento», Ars Longa, 5 (1994), p. 121.

26. Fernando Benito Doménech: Joan de Joanes. Una nueva visión del artista y su obra. Museo de Bellas Artes de Valencia, 31 enero - 26 marzo, 2000, pp. 36 y 236. 
más documentado de Alfonso V el Magnánimo encargado por los jurados de la ciudad de Valencia en 1557.

Habiendo descartado la autoría obvia o «natural» de Joanes para esta serie, se ha de volver a la obra y a la relectura de la escasa documentación que existe, apuntando una hipótesis de trabajo que es el hecho de que no fuera un encargo ducal. Esta propuesta se basa en dos premisas: esta serie no aparece citada, obviamente, en la relación de objetos enviados desde Ferrara en 1524 y 1527, pero tampoco en el inventario de bienes post mortem del duque realizado en 1550 , ni en la crónica del monasterio de 1555 , donde se incluyen todas las obras de arte de los duques como heredero y nuevo propietario, a diferencia de otras obras de las que sí constan referencias (ciertos retratos familiares, algunas pinturas devocionales, joyas y una gran cantidad de tapices entre las que se destaca la Pastorella). ${ }^{27}$ Además, la construcción del monasterio de San Miguel y de los Reyes se retrasó debido a los problemas económicos e incluso administrativos con pleitos y trabas jurídicas y, por tanto, resultaría factible que se pospusiera cualquier encargo artístico de relevancia. Todo esto nos conduce a una serie de autores de finales del siglo XVI y de mediados del siglo XVII a los que la bibliografía ha ido atribuyendo esta galería de retratos.

Un primer nombre es Apolinario Larraga. Orellana advierte que los retratos en papel realizados por Joanes «(el prior) los particularizó tanto (en el sentido de preservarlos), porque no se confundan y se equivoquen con otros que existen más afuera, en la misma celda, los cuales son copias de los referidos, hechas por Apolinario Larraga». ${ }^{28}$ Consideramos que este pintor sería el autor de otro retrato (este pareado) de los duques que tendría el prior en la celda, basado en la obra de Joanes, tal y como apunta el inventario de 1838 «un cuadro que contiene al duque y a la duquesa». Por tanto sería un retrato doble (no individualizado como aparece en la serie), y nada tendría que ver con los de la serie que nos ocupa. Una obra, la de Larraga, que por otra parte no consta en este museo. ${ }^{29} \mathrm{El} \mathrm{hecho} \mathrm{de} \mathrm{que} \mathrm{pintara} \mathrm{ese} \mathrm{retrato} \mathrm{pareado} \mathrm{a} \mathrm{partir} \mathrm{del} \mathrm{dibujo}$ de Joanes o que pintase una serie de retratos de venerables dominicos ayuda a pensar en que Larraga fuera el autor de la galería real, sin embargo, a nuestro parecer, poco tienen que ver la estética y la pincelada de ambas series.

Según Benito Doménech, Gregorio Bausá es el autor de la Adoración de los Reyes Magos que presidía el altar mayor del monasterio, localizada en este museo, lo cual le permitió atribuir por coincidencias estilísticas y formales

27. Luis Arciniega García: «El legado de la casa real de Aragón en Nápoles. Conservación y dispersión», Actas del XI Congreso del CEHA. Valencia, septiembre, 1996, pp. 114 y 116.

28. Marcos Antonio Orellana: Biografía pictórica valentina o vida de los pintores, arquitectos, escultores y grabadores valencianos, Valencia, ed. fac. Ayuntamiento de Valencia, 1967, p. 56.

29. Otras obras de este artista en el museo valenciano son los dos grandes lienzos con escenas de la vida de santo Domingo de Guzmán procedentes del convento dominico La Virgen entrega el rosario al santo (200 $\times 400 \mathrm{~cm}$. № inv. 3846) y la Aparición del Niño Jesús al santo $(200 \times 400 \mathrm{~cm}$. № inv. 3851). También se han de mencionar los óvalos con retratos de venerables de la orden originarios del mismo convento valenciano: $V$. $P$. Domingo de Córdoba ( ${ }^{\circ}$ inv. 3220), V. P. Jerónimo de Lanuza ( ${ }^{\circ}$ inv. 3221), V. P. Miguel de Santo Domingo ( ${ }^{\circ}$ inv. 3222), V. P. Juan de Puigventós (n inv. 3223), V. P. Juan Micó ( $\mathrm{n}^{\circ}$ inv. 3224) y V. P. Amador Espí (n inv. 3225). 
a este pintor o a su taller la galería de los reyes de Nápoles, si bien ningún cronista de la época ni los cita ni habla de su autoría. ${ }^{30} \mathrm{Al}$ margen de estas similitudes se puede considerar que Bausá bien podría haber realizado esta serie basándonos en el hecho de que asumió el encargo del lienzo principal antes mencionado. Al mismo tiempo, pocos pintores están formados para realizar retratos, aunque estos sean a través de estampas, y al menos sabemos por una noticia antigua de fray Joaquín Vivas que Bausá pintó en 1645 para el presbiterio de la cartuja de Valdecrist dos cuadros de los reyes fundadores don Martín y doña María de Luna, ambos con su sitial con sus alfombras y sus tapetes muy en consonancia con esta serie.

Sobre Gregorio Bausá (1590-1656) y su obra, poco más se ha dicho desde el esbozo biográfico realizado por Benito Doménech. Nacido en Sóller (Mallorca), llega a Valencia a partir de 1616, puesto que su nombre no figura entre los matriculados en el Colegio de Pintores. Sabemos por Orellana y por el mencionado fray Joaquín Vivas que trabajó para la cartuja de Valdecrist donde pintó doce lienzos sobre la vida de san Bruno, así como los retratos de los reyes antes citados. Las diferentes obras que se han ido atribuyendo a su estilo más o menos definido están dentro de un naturalismo ribaltiano con una influencia formal de Orrente, como es el caso del Prendimiento de Cristo del Museo de Bellas Artes de Castellón y del Santo Entierro del Museo del Patriarca en Valencia. También cabe destacar su importante corpus dibujístico agrupado, con otros autores, en el Álbum Lassala del Museo de Bellas Artes de Valencia. ${ }^{31}$ A este artista también se le atribuyeron durante mucho tiempo, posiblemente como extensión a esta galería de retratos, los dos retratos de Alfonso V, el Magnánimo y de Juan II, el Grande, pertenecientes al Museo de Bellas Artes de Valencia, para ornar la capilla de los Reyes en el Real Convento de Santo Domingo de Valencia y que finalmente se han atribuido a Vicente Salvador Gómez. ${ }^{32}$

Por otra parte, en una reciente exposición se barajó la posibilidad de que el retrato de Germana de Foix fuese de otro autor contemporáneo a Bausá: ${ }^{33}$ Antonio Bisquert (1596-1646), pintor valenciano que ante la falta de encargos en la Valencia de finales de la segunda década del siglo XVII marchó a tierras turolenses. ${ }^{34}$ Los parecidos formales en el rostro (cejas perfiladas cuyo sombreado sirve para formar la nariz, boca pequeña y labios prietos y barbilla

30. Fernando Benito Doménech: Los Ribalta y la pintura valenciana de su tiempo, Valencia, Lonja de Mercaderes, oct. - nov. 1987. Valencia, 1987, pp. 270-273.

31. Fernando Benito Doménech - José Luis Galdón: «El maestro del Álbum Lassala y Gregorio Bausá. Anotaciones al Corpus del dibujo valenciano del siglo XvıI», Archivo de Arte Español, Madrid, 266 (1994), pp. 105-118.

32. Retrato de Alfonso V, O/L, $209 \times 119 \mathrm{~cm}$. No inv. 3729 y Retrato de Juan II, O/L, $208 \times 120 \mathrm{~cm}$. № inv. 3571. Museo de Bellas Artes de Valencia. Sobre la atribución a Vicente Salvador Gómez se ha de ver. Victor Marco García: El pintor Vicente Salvador Gómez (Valencia, 1637-1678), Valencia, Institució Alfons el Magnànim, 2006.

33. David Gimilio SANZ: «Ficha catalográfica del retrato de Germana de Foix», Encrucijada de Culturas, Zaragoza, la Lonja, 4 jun. - 16 oct. 2008. Zaragoza, 2008, pp. 303-304.

34. Carlos Buil Guallar - Juan Carlos lozano lópez: El pintor Antonio Bisquert (1546-1646), Teruel, Museo diocesano, 23 mayo - 18 jun. 1995. Teruel, Instituto de Estudios Turolenses, 1995. 
sobresaliente que rompe el óvalo de la cara) son muy similares a los rostros que realizó Bisquert en el lienzo de Santa Úrsula y las once mil vírgenes para la catedral de Teruel.

Una tercera opción es remitirnos a los retratos de los reyes de Sobrarbe, condes antiguos y reyes de Aragón para la Diputación de Zaragoza que realiza el pintor italiano Felipe Ariosto a partir de 1586 y que desaparecieron durante los sitios de Zaragoza en 1808 al incendiarse el palacio gubernamental. ${ }^{35}$ Esta serie se encuentra ampliamente documentada y constaba de cuarenta lienzos (dos de ellos pintados por el pintor de corte Alonso Sánchez Coello) que obligó al pintor a desplazarse a Barcelona, Poblet, Huesca y Sijana para «ver y reconosçer algunos retratos al vivo que se hallan sepultados sus cuerpos en dichos lugares», añadiendo un concepto humanista del retrato por su fidelidad histórica. En cualquier caso, esta serie tuvo un gran éxito histórico como repertorio iconográfico, puesto que Ariosto repitió modelos para una serie similar de condes y condes-reyes para Barcelona y se copió, al parecer, para el Alcázar de Madrid poco después de 1587, así como para otras instituciones y palacios aragoneses. Además, esta serie se copió en 1634, a petición del rey Felipe IV, para decorar una de las salas del palacio madrileño del Buen Retiro por los pintores Francisco Camilo, Pedro y Andrés Urzanqui y Vicente Tió, y es gracias a ella por la que se tiene referencia de aquella serie primigenia.

Aquellos retratos de Ariosto y por ende los madrileños comprendían un retrato de cuerpo entero con el escudo que en la época de los retratados identificaba a Aragón, una inscripción latina y el escudo personal con su empresa y mote, de este modo el retrato tomaba un carácter emblemático que en el caso de la serie de los reyes de Nápoles no existe salvo en uno de ellos, el del rey Alfonso II de Aragón que repite fielmente la iconografía del monarca Jaime II el Justo [Fig. 13], el escudo de la casa real de Aragón y su escudo personal que presenta en la divisa, balanza de oro sobre azur y en el mote «SEMPER AQUA» que alude al respeto escrupuloso de Jaime II a los fueros y costumbres aragoneses. ${ }^{36}$ Es cierto que los retratos de Alfonso II de Aragón y de su esposa Hipólita María Sforza escapan levemente al resto de la serie por características formales pero no estilísticas: son más altos $(230 \mathrm{~cm}$ frente a los $175 \mathrm{~cm}$ de media del resto) y no llevan escudos que aludan a la dinastía napolitana o milanesa en el caso de la reina Hipólita. En cualquier caso, este retrato del rey Alfonso II de Aragón responde a un modelo iconográfico distinto al del resto de la serie que al menos supone el conocimiento de la serie aragonesa por parte del artista. La existencia de estos dos retratos ajenos a la serie pero ciertamente hermanados, pudo ser aprovechado bien por el artista, bien por los monjes, para completar esta galería.

35. Carmen Morte García: «Pintura y política en la época de los Austrias: Los retratos de los reyes de Sobrarbe, condes antiguos y reyes de Aragón para la Diputación de Zaragoza (1586), y las copias de 1634 para el Buen Retiro de Madrid (I)», Boletín del Museo Prado, tomo XI, 29 (1990), pp. 19-35.

36. Ibidem, p. 22 


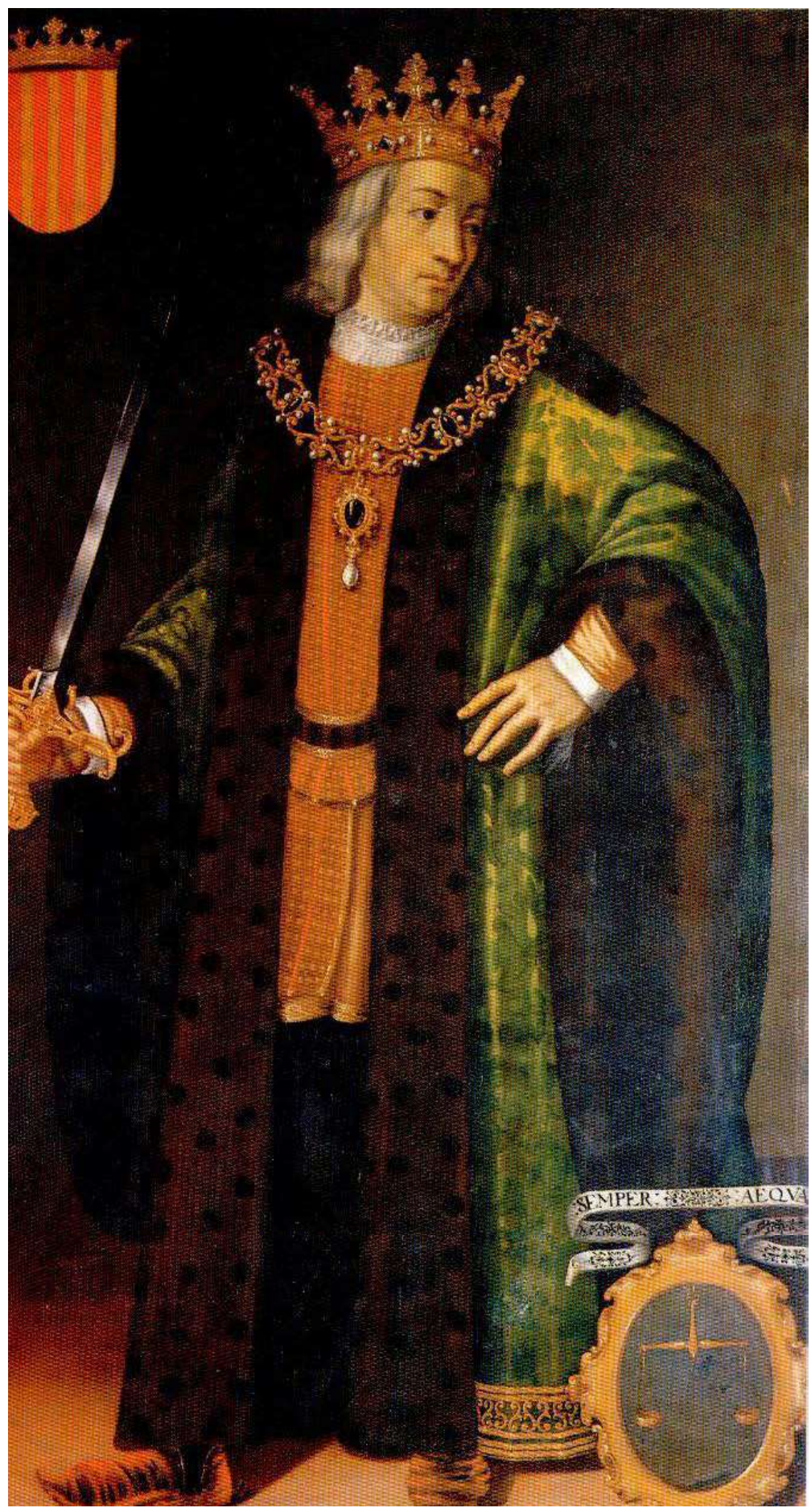

Fig. 13. Felipe Ariosto, Retrato de Jaime II el Justo, Museo Nacional del Prado 
Carmen Morte, en los artículos sobre Ariosto, cita a Rolán de Mois, pintor flamenco de reconocido prestigio que trabajó en tierras aragonesas y que fue calificado como «maravilloso retratador» según Jusepe Martínez como colaborador de Felipe Ariosto. Su galería de retratos de la familia Villahermosa encargados por Martín de Gurrea y Aragón o los retratos de los justicias de Aragón para la Diputación del reino de 1578 así lo confirman y nos permiten apuntar como un autor más de esta serie. Un nombre, el de Rolán de Mois, que en parte ha estado vinculado también a la memoria del Museo de Bellas Artes de Valencia, puesto que fue considerado por Tormo (junto al nombre de Antonio Stella) el autor de la serie de la familia Vich (una vez superada la manida atribución a Juan Ribalta). ${ }^{37}$ Benito Doménech retoma la segunda atribución de Tormo y considera que el autor de esta serie es el pintor Antonio Stella que trabajó en Valencia entre 1583 y 1584 al servicio del patriarca Juan de Ribera, y pasó luego a Valladolid donde desarrollaría su actividad artística. ${ }^{38}$

Sin poder entrar en disquisiciones de atribución entre Rolán de Mois y Antonio Stella, sí se ha de decir que la comparación entre una y otra no vislumbra apenas paralelismos que permitan atribuir la serie de la dinastía napolitana a cualquiera de estos dos artistas arriba mencionados. Mientras que en la serie Vich son retratos de medio cuerpo, de fondos neutros, con inscripciones que identifican a los personajes y cuyos rostros son más realistas, están más individualizados, participando de un primer naturalismo; en la galería que nos ocupa, los retratos son más variados con fondos abiertos a un paisaje o dentro de una sala, las posturas son más forzadas, los rostros más anodinos e incluso repetitivos a la búsqueda de un icono con leves elementos que los individualiza, como si se vacilara entre una tipificación de rasgos y elementos propios del retrato dinástico y una individualización de la figura.

$\mathrm{Al}$ margen de estos dos autores citados que ayudan a completar el estudio sobre las posibles atribuciones de esta galería de retratos, creemos que las dos opciones más plausibles serían la de Gregorio Bausá y la de Antonio Bisquert. La primera por ser un pintor vinculado al monasterio de San Miguel y de los Reyes con obras importantes como el lienzo de los Reyes Magos del altar mayor y por su vertiente retratística. En el caso de Antonio Bisquert, las similitudes formales en los rostros del gran lienzo de Santa Úrsula y las once mil vírgenes con los retratos femeninos de las reinas permiten apuntar esta posibilidad.

37. La serie está formada por las efigies de Luis Vich Manrique de Lara, su mujer Mencía y sus hijos y nietos hasta conformar once familiares. Elías Tormo: Los Museos. Guías-Catálogo: Valencia, 2 vols. Madrid, Centro de Estudios Históricos, 1932, p. 60.

38. Fernando Benito Doménech: El patio del palacio del Embajador Vich. Elementos para su recuperación. Valencia, Museo de Bellas Artes de Valencia, 30 jun. - 12 jul. 2000, Valencia, 2000, p. 29. Sobre Antonio Stella se puede consultar M. a Antonia Fernández DEL Hoyo: «Antonio Stella. Pintor italiano», Boletín del Seminario de Arte y Arqueología, Universidad de Valladolid, 1980, p. 507. 
La representación del poder en la Corona de Aragón. La dinastía de la Casa de Aragón en Nápoles

Es en este marco donde se tendría que hablar de dos aspectos íntimamente imbricados, cómo se representa al rey en la Corona de Aragón y su relación con una dinastía reinante como lo es la Casa de Aragón en Nápoles, y el porqué de esta serie, vinculada tradicionalmente al monasterio de San Miguel y de los Reyes.

La galería de retratos reales en este ámbito cultural no se diferencia especialmente del resto de territorios de la Europa cristiana, los retratos de los monarcas acompañados de las insignias de poder y emblemas heráldicos (el trono, la corona, el cetro, el orbe, la espada, las ricas vestiduras...), en definitiva, símbolos tangibles de la realeza responden, la mayor de la veces, «a una imagen imaginaria más que real o histórica» en palabras de Carmen Morte ${ }^{39}$ Unos retratos de carácter retrospectivo promovidos no tanto por la corte como por las instituciones gubernamentales que trataban de recuperar la memoria histórica de su territorio muchas veces cuestionada u olvidada. Es el caso de la serie de los reyes de Sobrarbe, condes antiguos y reyes de Aragón para la Diputación de Zaragoza que realiza el pintor italiano Felipe Ariosto a partir de 1586, ya mencionada anteriormente, o la que nos ocupa donde, la orden jerónima quiso más que recordar, perpetuar el recuerdo del fundador del monasterio y su familia.

En los retratos de la casa real de Aragón en Nápoles se plasma un proceso de idealización de los retratados, una referencia imaginaria más que veraz, donde la retratística, en sentido estricto (solo destacable en el caso de Ferrante I), se difumina para conformar un retrato irreal, con paisajes ilusorios e indumentaria repleta de anacronismos, donde el poder real está representado por aquellos objetos que se identifican de manera rápida con la monarquía, que se asocia a su vez, con el propio linaje a través de los escudos nobiliarios con una función legitimadora de la dinastía. Este carácter legitimador de la casa real de Aragón en Nápoles lo inició tempranamente el rey Alfonso el Magnánimo como heredero de la casa de Trastámara y como conquistador de la ciudad partenopea, configurando una iconografía real y de príncipe renacentista auspiciada por los artistas y eruditos que le rodeaban en la corte. A su vez, esta imagen de legitimidad supo transmitirla a su hijo Ferrante I de Aragón [Fig. 14] como heredero del trono napolitano e iniciador de esta nueva casa real, de hecho, la imagen de Ferrante I fue profusamente reproducida en monedas, medallas, esculturas y miniaturas de la época como el busto del Louvre atribuido a Pietro de Milano o la Pala de Guiulio Scorciatis. También fue retratada Isabel de Chiaromonte, esposa de Ferrante, en el retablo de San

39. CARmen Morte GarCía: «La representación del rey en la Corona de Aragón», La Corona de Aragón. El poder y la imagen de la Edad Media a la Edad Moderna, Valencia, Museo de Bellas Artes de ValenciaCentro del Carmen, 16 en. - 17 abr. 2006, Valencia, 2006, pp. 55-93. 


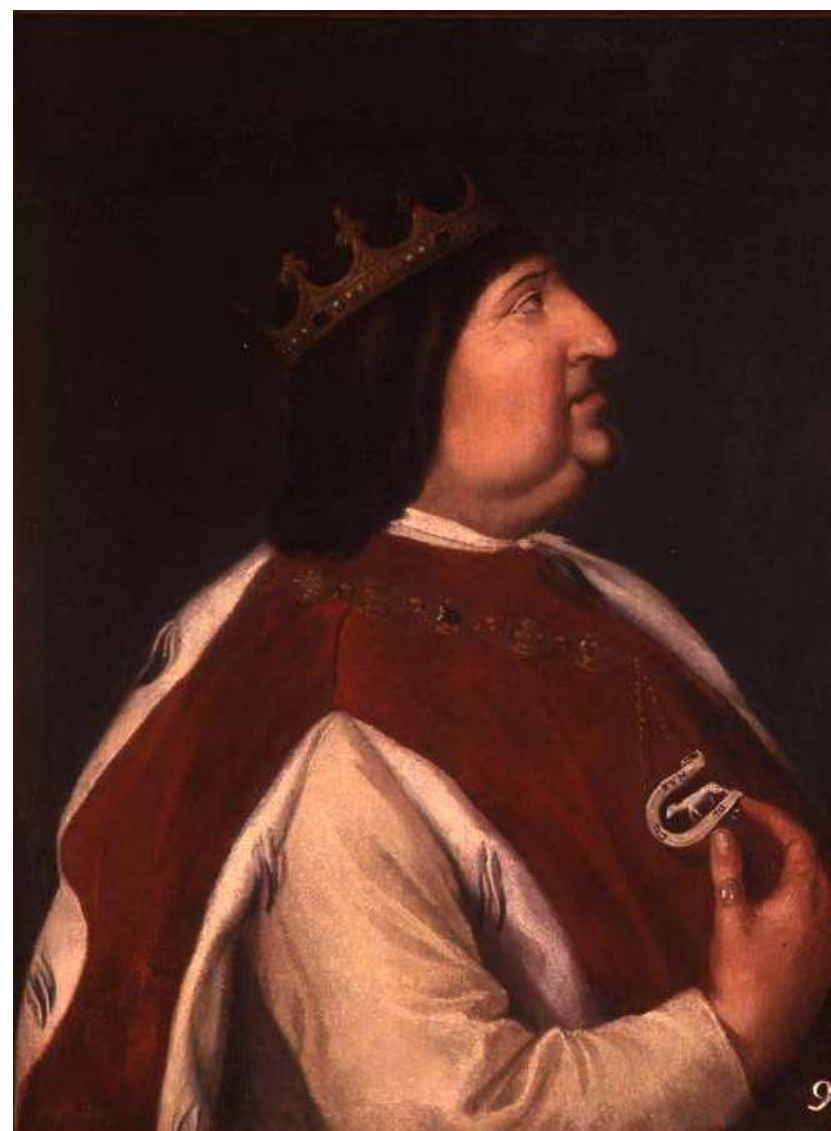

Fig. 14. Anónimo, Retrato de Ferrante I de Nápoles, Museo de Bellas Artes de Valencia, colección de la Real Academia de San Carlos

Vicente Ferrer para la iglesia de San Pedro Mártir de Nápoles, con sus hijos Alfonso y Leonor.

En definitiva, esta galería de retratos procedente de San Miguel y de los Reyes, por cronología, está en la línea de la Sala de los Reyes que Felipe II instaló en el Palacio Real del Pardo donde albergó las imágenes de familiares y antepasados dentro del principio de legitimidad dinástica, ${ }^{40}$ un paralelismo que avala el que la serie icónica de los reyes napolitanos no fuese tanto un encargo del duque de Calabria, sino más bien un homenaje de los monjes jerónimos a su patrono y familia, la extinta casa real de Aragón en Nápoles, así como una forma de enaltecimiento para el propio monasterio valenciano.

40. Sobre el Palacio Real del Pardo se ha de consultar MARía KuSCHE: «La antigua galería de Retratos del Pardo: Su reconstrucción arquitectónica y el orden de colocación de los cuadros», Archivo Español de Arte, LXIV, 253 (1991), pp. 1-28. 
